\title{
Morphological and structural analysis in the Anaga offshore massif, Canary Islands: fractures and debris avalanches relationships
}

\author{
P. Llanes ${ }^{1, *}$, A. Muñoz ${ }^{2}$, A. Muñoz-Martín ${ }^{1}$, J. Acosta ${ }^{2}$, P. Herranz ${ }^{2}$, A. Carbó ${ }^{1}$, C. Palomo ${ }^{2}$ \& \\ ZEE Working Group** \\ ${ }^{1}$ Universidad Complutense de Madrid. Facultad C.C. Geológicas. Departamento de Geodinámica. 28040 Madrid, \\ Spain \\ ${ }^{2}$ Instituto Español de Oceanografía. Grupo de Cartografía Multihaz. C. de María ${ }^{\circ}$ 8. 28002 Madrid, Spain \\ *Corresponding Author (Phone: +34-913944834; Fax: +34-913944631; E-mail: pllanes@geo.ucm.es)
}

Key words: Anaga massif, bathymetry, debris avalanche, fractures, Tenerife island

\begin{abstract}
As part of the 'National Hydrographic and Oceanographic Research Plan for the Spanish Exclusive Economic Zone', multibeam bathymetry and seismic reflection profiles were obtained in the Canary Islands aboard the R/V Hespérides. The submarine flanks of the Anaga offshore extension of Tenerife Island are here studied to analyze its geomorphology. In the north sector of the Anaga submarine massif, the extension of the Anaga Debris Avalanche has been mapped for the first time, and a volume of $36 \mathrm{~km}^{3}$ was calculated. The relationship between the Anaga and Orotava Debris Avalanches is also described. Faulting has been recognized as a key process for the occurrence of debris avalanches and the growth of volcanic lineaments. Moreover, faulting affects previous structures and the channelling of debris flows. Structural analysis shows the typical radial pattern of an oceanic island. In addition, a NE-SW dominant direction of faulting was obtained, consistent with the Tenerife Island structural trend seen in the Anaga Massif and Cordillera Dorsal. NW-SE and E-W are two other main trends seen in the area. Special interest is manifest in two long faults: 'Santa Cruz Fault' bounds the southern edge of Anaga offshore Massif with a length of $50 \mathrm{~km}$ and a direction that changes from NE-SW to almost E-W. The Güimar Debris Avalanche was probably channeled by this fault. The 'Guayotá Fault' was recognized in several seismic profiles with a N-S direction that changes towards NW-SE at its southern end. This fault affects the more recent sediments with a vertical offset of 25-30 m, along $60 \mathrm{~km}$. It has been interpreted as a transpressive strike-slip fault.
\end{abstract}

\section{Introduction}

Multibeam mapping of the seafloor around oceanic islands has significantly increased the understanding of the evolution of volcanic islands. That is because the submerged zones of oceanic islands are considerably bigger than the subaerial parts, and they represent the initial growth stages and some of the major volcanic risk.

\footnotetext{
**F. Carrillo ${ }^{\mathrm{a}}$, C. Matéa $^{\text {, M. Ballesteros }}{ }^{\mathrm{b}}$, M. Vaquero ${ }^{\mathrm{b}}$, J. MartínDávila $^{c}$, M. Catalán ${ }^{c}$ and J.A. Marín ${ }^{c}$.

${ }^{a}$ Instituto Hidrográfico de la Marina. Cádiz.

${ }^{\mathrm{b}}$ Instituto Español de Oceanografía. Madrid.

${ }^{\mathrm{c}}$ Real Observatorio de la Armada. S. Fernando, Cádiz.
}

A great part of the studies related to the submarine flanks of the Canary Islands have described and characterized the giant landslides, studied the processes and age of their formation and compared them with the Hawaiian landslides (Holcomb and Searle, 1991, Carracedo, 1994; Watts and Masson, 1995; Masson, 1996; Geisslinger et al., 1996; Teide Group, 1997; Funck and Schmincke, 1998; Urgeles et al., 1999; Stillman, 1999; Carracedo, 1999; Watts and Masson, 2001; Krastel et al., 2001; Masson et al., 2002). A few other studies have focussed on seismostratigraphy, submarine volcanism or deep-sea sediment physical properties (Roberts and Cramp, 1996; Urgeles et al., 1998; Gee et al., 2001; Urgeles et al., 2000). 
A previous study (Mitchel et al., 2003) was carried out in the region of Anaga with multibeam data. It described erosion process and used a geomorphology method to calculate the erosion depth. From the comparison of the old and eroded flank of Anaga with the young, mostly unaltered flank of El Hierro, these authors inferred a mean depth of Anaga's submarine erosion of $100 \mathrm{~m}$. They also mapped canyon chutes and topographic peaks in the area.

In this paper we use geophysical methods to examine both the morphology and structure of the seaward extension of the Anaga Massif (NE Tenerife Island) in order to define the geological processes that controlled the geological evolution of this area. We have mapped erosional, volcanic and structural features. Structural lineations provide directions where the erosive processes preferentially take place. Because of the possible relationship between structural lineations and erosional process we carry out a structural analysis. We also discuss and try to establish the relationships between the submarine and the subaerial processes in relation with the debris avalanches of this area.

\section{Geological setting}

The Canary Islands are an archipelago formed by seven volcanic islands located in the eastern Atlantic Ocean, at the border of the northwest African continental margin (Figure 1). These islands are sited on Upper Jurassic oceanic crust (Roest et al., 1992) of the African plate, between magnetic anomalies M21 (148 Ma) and S1, interpreted as true oceanic crust (Roest et al., 1992) and dated by Klitgord and Schouten (1986) as 175 Ma. The African plate has been more or less stationary during the subaerial growth stage of Canary Islands, with an average of movement in this region of about $10 \mathrm{~mm} / \mathrm{yr}$ since 60 Ma (Duncan, 1981; Morgan, 1983). The Canary volcanism is much younger than the underlying oceanic crust. The oldest subaerial volcanic activity occurred on Fuerteventura at 20 Ma (Coello et al., 1992), whereas the youngest volcanic activity happened in La Palma in historical time.

The structural evolution of a volcanic oceanic island may result from a complex interaction of magmatism with the regional stress field and the local stress field generated during the growth of the island itself (Marioni and Pasquarè, 1994). Volcanic structures are characterized by steep and gravitationally unstable slopes, and are commonly associated with recent seis- mic activity that favours the initiation of catastrophic slope failures (Acosta et al., 1997). Landslides are considered key processes in the evolution of oceanic islands, because they are a response to the volcanic edifice exceeding the mass that the island can support (Masson et al., 2002).

Tenerife island has a triangular shape and is the largest $\left(2058 \mathrm{~km}^{2}\right)$ and highest $(3718 \mathrm{~m})$ of the Canaries, occupying the central position in the archipelago. This island is considered a triple rift zone, with a more complex scheme than others such as El Hierro, because it has a stratovolcano-type central volcano of differentiated (trachytic-phonolitic) magmas (Teide-Pico Viejo Volcanic Complex; Carracedo, 1994) (Figure 2).

The subaerial part of Tenerife was originally constructed by fissure eruptions of ankaramite, basanite and alkali basalts, that occurred between 12 and 3.3 Ma (Ancochea et al., 1990). According to Hausen (1956), the 'basaltic tableland series' products of these eruptions, are crossed by numerous dikes and outcrop at the three corners of the island, Anaga, Teno and Roque del Conde (Figure 2). They are known as the Old Basaltic Series.

In the recent past, it appears that Tenerife, together with El Hierro and La Palma, has been the most active of the Canary Islands, in terms of both volcanic and landslide activity (Urgeles et al., 1997). Such voluminous Quaternary volcanic activity was focussed on the island's centre (Cañadas Volcano, 1.9-0.2 Ma) and on a chain of basaltic eruption centres spreading from the central volcano to the northeast (Cordillera Dorsal, peak activity, 0.8 Ma) (Ancochea et al., 1990).

Debris avalanche deposits were first recognised offshore Tenerife by Watts and Masson (1995) and subsequent studies mapped at least four avalanche events offshore the north coast (Teide Group, 1997; Watts and Masson, 1998; Watts and Masson, 2001) and five in the south-eastern flank of Tenerife (Krastel et al., 2001). The valley of Güimar and shortly afterwards the Orotava valley were formed by large landslides after $0.8 \mathrm{Ma}$, and probably before $0.6 \mathrm{Ma}$. The Cañadas caldera may have had several collapse phases and the present caldera was formed by a landslide since 0.2 Ma (Ancochea et al., 1990). However, the key aspects of the history of the flanks of Tenerife are controversial, including the number of landslide events, their timing and nature and their possible relationship with onshore structures.

Anaga Peninsula, the northeast appendix of Tenerife, is $13 \mathrm{~km}$ wide and $26 \mathrm{~km}$ long and reaches $1024 \mathrm{~m}$ 


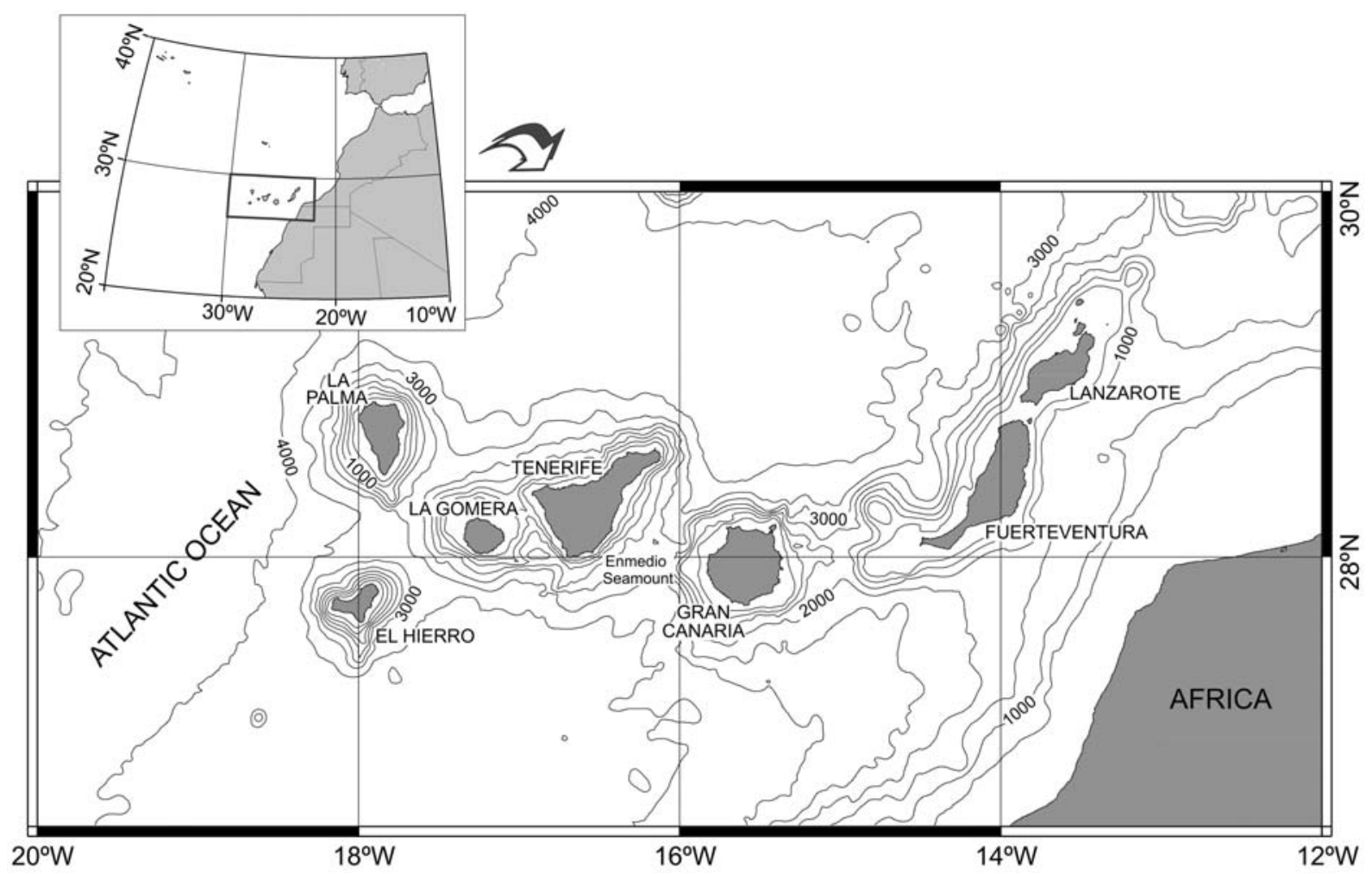

Figure 1. Location map of the Canary Archipelago. Depth in meters.

in height above sea level. It is incised by narrow valleys up to $500 \mathrm{~m}$ deep, mostly trending N-S to NNWSSE. Anaga grew between 6.5 and 3.6 Ma, with major activity occurring between 6 and $4.5 \mathrm{Ma}$. It is formed by a complex sequence of alkali basaltic lava flows and volcanoclastic layers, intruded by subvolcanic bodies like dykes, domes and laccoliths of basalts, trachybasalts, trachytes and phonolites (Ancochea et al., 1990). Anaga Peninsula is linked to the central volcano of Tenerife (Cañadas Volcano) by a chain of basaltic centres, the Cordillera Dorsal (Figure 2).

\section{Methods}

The present study is part of the National Hydrographic and Oceanographic Research Plan for the Spanish Exclusive Economic Zone (ZEE), and was carried out aboard the Spanish R/V Hespérides.

The data we present here were collected in the $\mathrm{Ca}$ narian Archipelago in June 1999, during the ZEE-99 cruise, in an area that covers $7050 \mathrm{~km}^{2}$ of the Tenerife submarine flank, where we obtained bathymetric data and ultra-high resolution seismic profiles along 30 track lines (Figure 3). Five additional track lines of Teide 95 cruise were used to complete survey of the west side of Anaga offshore Massif.

The bathymetric data were used to identify the various morphologic features present on the Anaga insular slopes and to map their distribution, whereas the seismic reflection profiles were used to determine their internal structure.

Swath bathymetric data were obtained with a Simrad EM-12s System, giving 100\% coverage of the seafloor. The EM-12s is a multibeam echosounder which transmits 81 beams across a total swath opening of $120^{\circ}$, producing a swath width equal to 3.5 times the water depth. The system works at a frequency of $12.5 \mathrm{kHz}$ and is able to resolve depths of a few metres. These data were logged using Simrad's Mermaid and Merlin software and subsequently processed using Neptune and C-floor software. This allows the creation not only of bathymetric charts but also Digital Terrain Models and 3D block diagrams of the surveyed area. We have attempted to remove all artifacts on the maps, but a few remain. The more significant ones were 


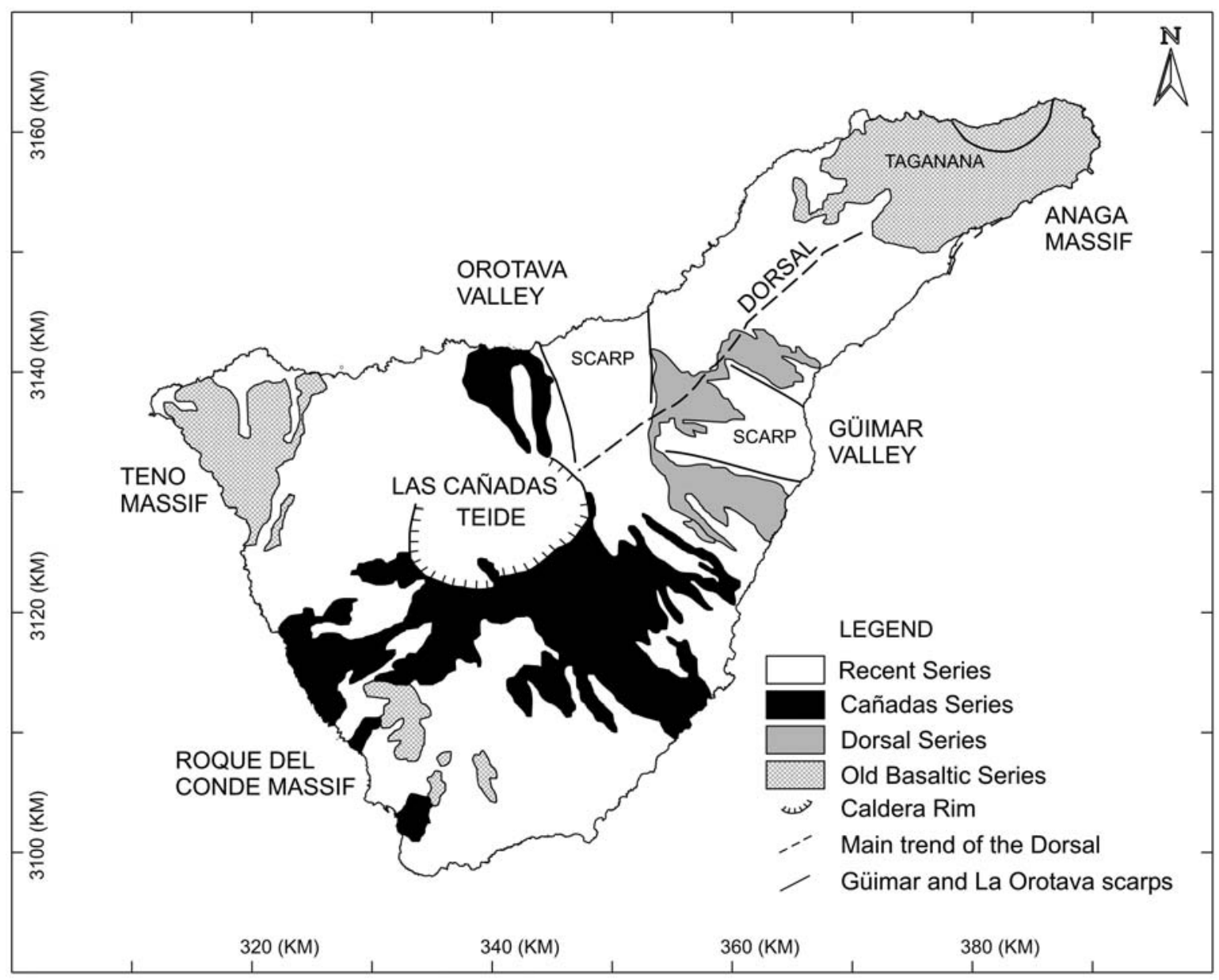

Figure 2. Simplified geologic map of Tenerife island. Modified from Ancochea et al. (1990). The coordinates are Universal Transverse Mercator (UTM) Zone 28 distances in $\mathrm{km}$.

found in the flat seafloor of the abyssal plain in the NE area (starting at the $3625 \mathrm{~m}$ contour) where an E-W fabric is seen parallel to the ship tracks. Other artifacts with a N-S fabric are seen on the island flanks.

Three morphologic maps were then produced from bathymetry data, including a contour map (Figure 4), a slope map (Figure 5) and a shaded relief map (Figure 6). Ship's navigation, which is critical for quality control of the multibeam data, was by means of two simultaneous Differential GPS systems, integrated into R/V Hespérides central navigation system which transmits at any given time the ship's position to all the scientific stations via ethernet. Our navigation data has a $5 \mathrm{~m}$ precision.

Seismic reflection profiles were recorded using a Simrad Bentech Topographic Parametric Sonar, 018 bottom parametric source. This source has two primary frequencies, 15 and $18 \mathrm{kHz}$, giving secondary frequencies of 0.5 and $5 \mathrm{kHz}$. Thereby, it is possible to obtain very high resolution profiles, although with a corresponding lack of penetration that is implicit in the high resolution system.

\section{Anaga offshore proximal region}

\section{General structure}

To study the proximal offshore Anaga region only the bathymetric data have been used because ultra high resolution seismic profiles have a poor quality in those areas where the slopes are significant.

The offshore extension of the Anaga Massif is a wide structure extending seaward from the coast. It shows an elongated shape, with a major axis of $50 \mathrm{~km}$, 


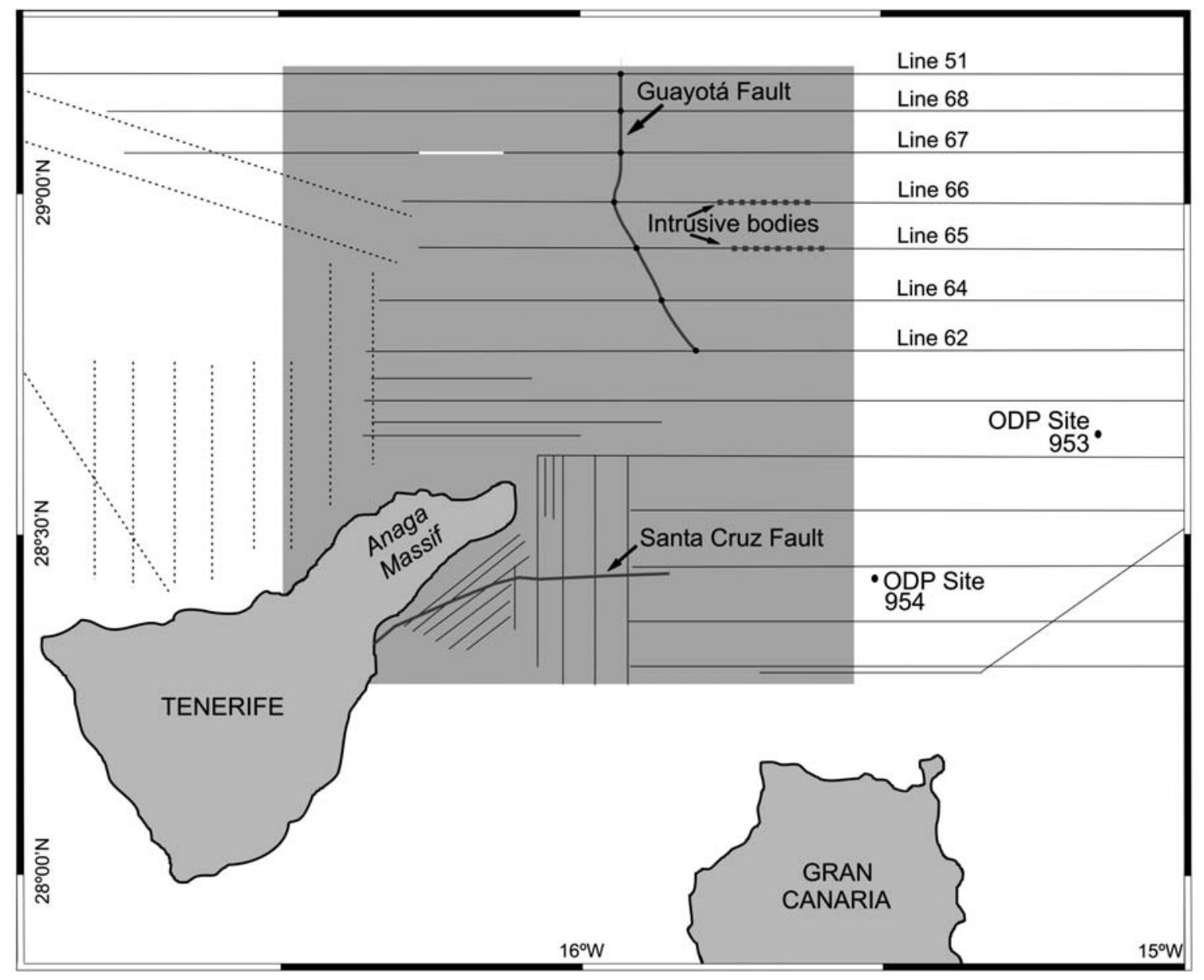

Figure 3. Track lines map. Geophysical data collected during ZEE-99 cruise is shown as black lines and survey lines collected during Teide cruise is shown as black dashed lines. Grey square box is the location of studied area. Circles mark the locations of Ocean Drilling Program (ODP Sites 953 and 954). Grey line mark situation of 'Guayotá Fault' and 'Santa Cruz Fault' and grey dashed line mark situation of intrusive bodies (see text, section 5). White line mark situation of the seismic segment display in Figure 13.

oriented NE-SW. The offshore structure starts with a relatively flat submarine shelf (labelled $\mathrm{S}$ in Figure 7) with slope gradients less than $1^{\circ}$ (Figure 5). This is probably the result of wave erosion during Pleistocene glacially induced regressions (Teide Group, 1997). Mitchell et al. (2003) pay attention to the asymmetric effect of subaerial and submarine erosion of the Anaga Massif, finding that the north subaerial slopes of the island are steeper than those to the south, implying that the drainage divide lies north of the massif's center. From the analysis of trade winds data Mitchell et al. (2003) deduced that a persistently greater precipitation to the north and a more powerful sea leads to a greater width of the abrasion platform in the north of Anaga.
The shelf break lies at $125 \mathrm{~m}$ depth, where the slope gradient locally increases to more than $30^{\circ}$. The shelf break is reached at different distances from the coast, from $500 \mathrm{~m}$ in the south to more than $6000 \mathrm{~m}$ at the NE (Figure 4) where the shelf reaches its maximum development. Northeastwards, the Anaga offshore massif has its maximum development reaching the $3500 \mathrm{~m}$ depth contour. In this area, there are numerous pinnacles recognized in the bathymetric map (Figure 4). They are sometimes elongated or aligned downslope in groups of two or three, suggesting that they could be related to dyke activity radiating from a central volcanic zone. The pinnacles in the studied area are 1-3 km across and 100-200 $\mathrm{m}$ high. Other 


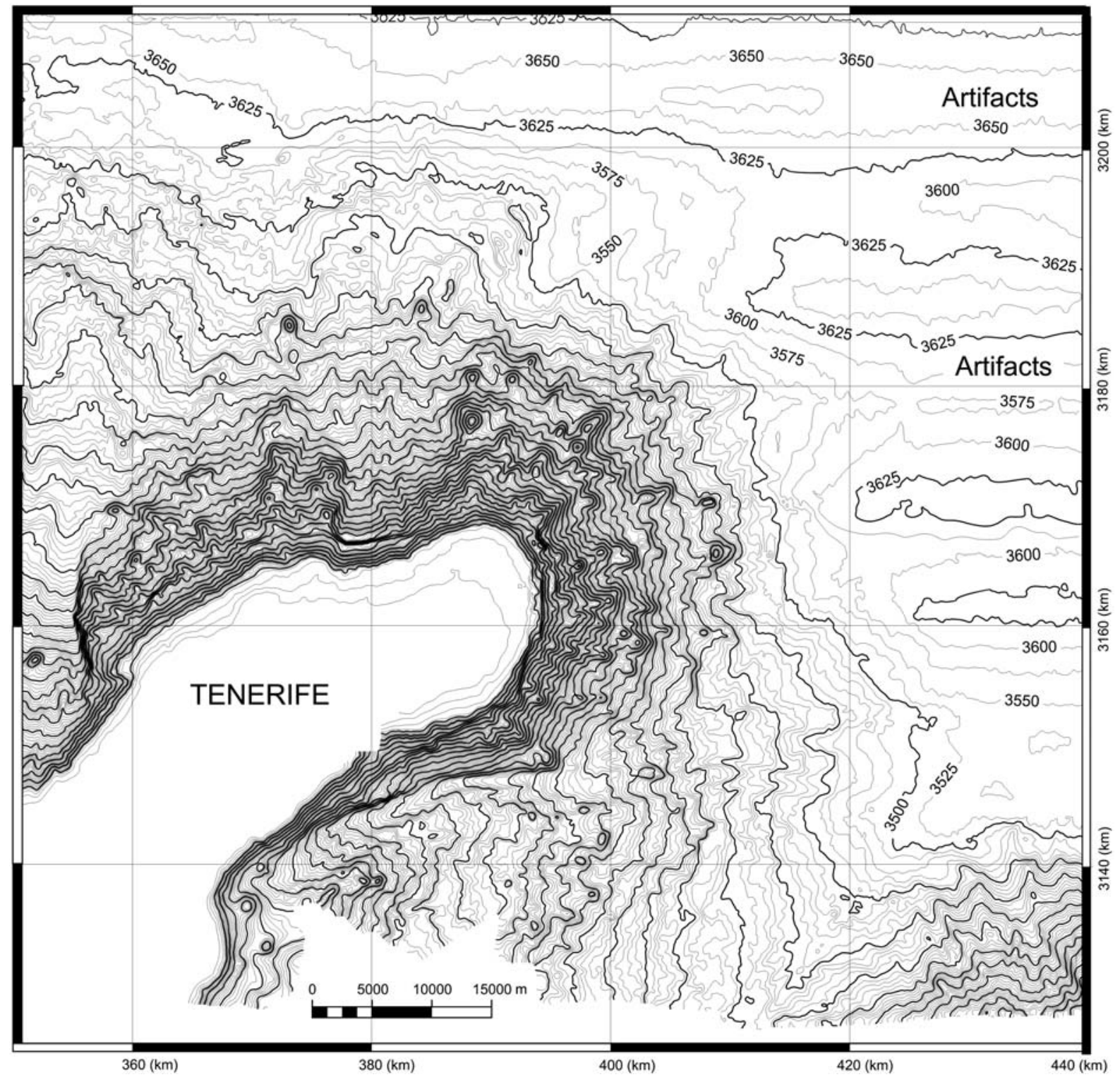

Figure 4. Bathymetric map of NE Tenerife. Multibeam coverage of $100 \%$. The contour interval is $25 \mathrm{~m}$. The coordinates are Universal Transverse Mercator (UTM) Zone 28 distances in km. Water depth in meters.

pinnacles, similar to these have been recognized and studied in the offshore continuation of volcanic rift zones on El Hierro (Gee et al., 2001; Mitchell et al., 2003) and Tenerife Island (Mitchell et al., 2003).

Dredged rocks in this area have been studied by Abratis et al. (2002), whose results indicate that igneous compositions correspond to alkali-rich ankaramites and basanites. The geochemical/isotopic signature of the Anaga Massif is apparently not restricted to the northeast part of the island itself, but is also characteristic of the Enmedio Seamount, located in the channel between Tenerife and Gran Canaria islands (Figure 1). Enmedio Volcano is the biggest submarine volcano in the surrounding area of Tenerife, reaching $660 \mathrm{~m}$ from a depth of $3300 \mathrm{~m}$ with a conical shape. It was first discovered by Schmincke and Rhim (1994) and later mapped in official bathymetric charts by Palomo et al. (1998). Its composition was studied by García-Cacho et al. (2000) and Abratis et al. 


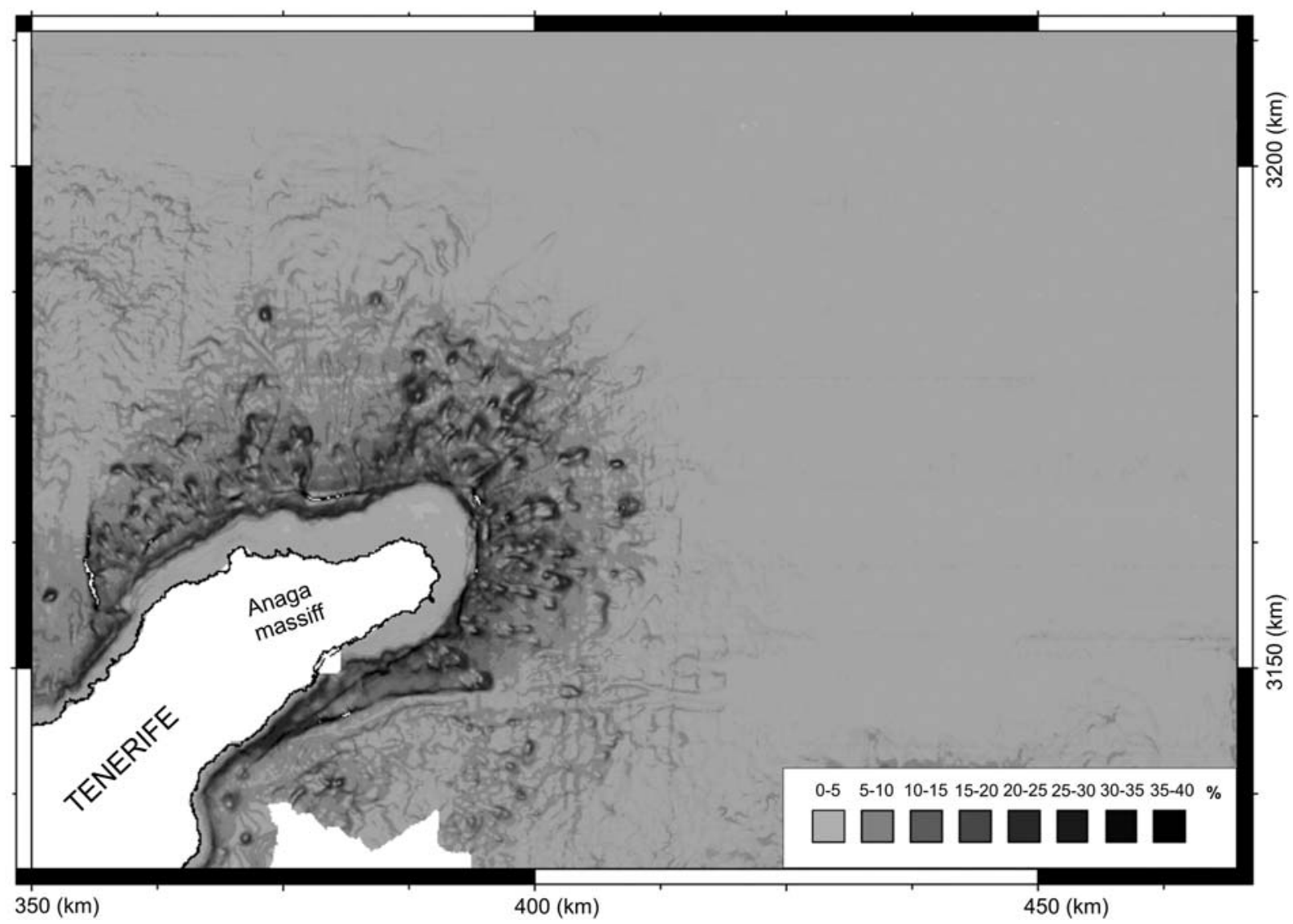

Figure 5. Slope map of NE Tenerife submarine region; dark areas are steepest slopes. Coastline is shown by solid black line. Image derived from 100-m gridded data. The coordinates are Universal Transverse Mercator (UTM) Zone 28 distances in km. For each particular point the slope is based on the direction of steepest descent or ascent at that point in a way that across the surface the gradient direction can change (the operation is similar to the way a First Directional Derivative is calculated but it defines the gradient direction at each point on the map automatically).

(2002), who concluded that Enmedio Volcano was comprised of benmoreites (Na-rich trachyandesites).

\section{North sector}

In the north of Anaga offshore massif area, we identify the result of mass wasting movements associated with slope failures, as demonstrated by the multi-beam bathymetry (Figure 4). Debris avalanche deposits were first recognised offshore Tenerife by Watts and Masson (1995) who noted that these deposits covered much of the submarine northern flank of the island. Their volume was estimated at $1000 \mathrm{~km}^{3}$ by the Teide Group (1997). Our data show the presence of two fanlike structures where the bathymetric contours bulge seaward (Figure 4):

One of these aprons is located to the NW of the massif, at the end of a channel that limits the Anaga offshore structure to the west and has been recognised and studied in previous works as the 'Orotava Debris Avalanche' (ODA) (Teide Group, 1997; Watts and Masson, 2001; Masson et al., 2002).

The other lobe, called 'Anaga Debris Avalanche' (ADA), is the easternmost collapse deposit of Tenerife and was identified by Masson et al. (2002) based on the general bathymetric map, although its morphology was neither mapped nor completely studied due to the lack of detailed data in this area.

\section{Orotava Debris Avalanche (ODA)}

The Orotava Debris Avalanche is one of the largest landslides that has occurred in the Canary Islands (Masson et al., 2002) and can be traced upslope towards the Orotava Valley on Tenerife, where a flat floor flanked by steep scarps is seen (Palacios, 1994). This is supposed to be the product of lateral collapse 


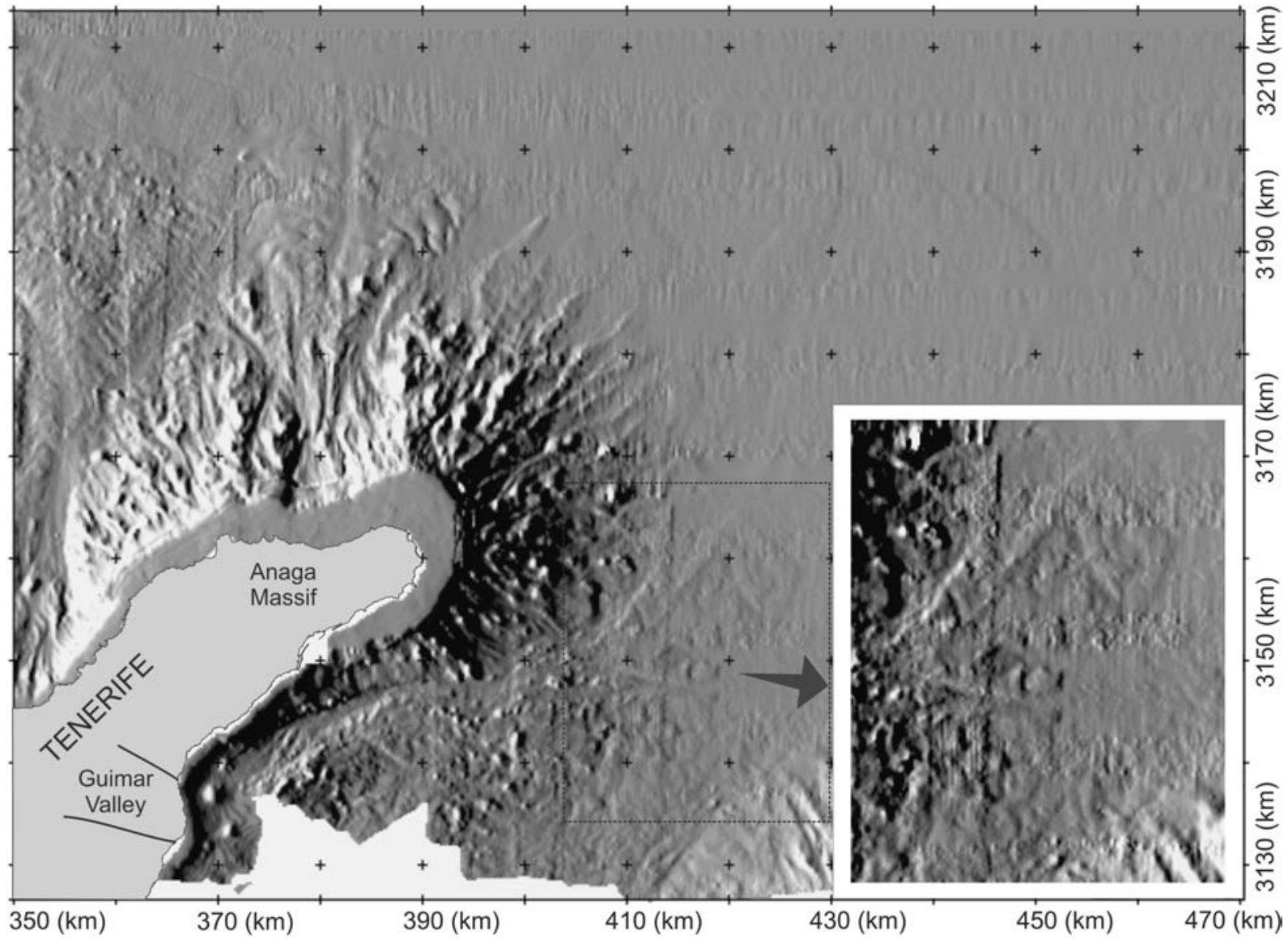

Figure 6. Shaded relief bathymetric map of NE Tenerife; apparent illumination from the northeast. Image derived from 100-m gridded data. The coordinates are Universal Transverse Mercator (UTM) Zone 28 distances in $\mathrm{km}$.

of the Cañadas Volcano, estimated between 540 and $690 \mathrm{ka}$ by the K/Ar dating of basaltic lavas in the upper part of the landslide scarp (Cantagrel et al., 1999).

The new data show that there is an abrupt change in the morphology of the area that limits the Anaga Massif structure offshore to the west. It can be deduced from the detailed observations based on bathymetry data that this limit has an original structural control and that faulting processes caused the abrupt change limiting the Anaga Massif in that area. This should have been favoured by the fact that Anaga Massif grew as an independent volcano that later volcanism linked to the dorsal series (Ancochea et al., 1990). The ODA was confined by this limit and the sediment apron also changed its morphology across this structure (Figure 6). However, it can be argued whether the avalanche was confined by the fault or if the scarp was created dur- ing the avalanche, indicating a purely morphological feature.

The roughness of the lobe is due to the presence of many small topographic highs between 30 and $110 \mathrm{~m}$ in height and between 50 and $1140 \mathrm{~m}$ in diameter. Limitation in the resolution of the bathymetric systems does not allow us to image highs less than $50 \mathrm{~m}$ diameter. Most of them can be interpreted as exotic blocks resulting from transport by the flow processes that formed the debris apron. However, some others seem to be pinnacles related to volcanic activity, but the resolution of the data is insufficient to determine the details of the morphology.

In the northeast area of the ODA, longitudinal pressure ridges have been identified (labelled P, Figure 7). These typical flow structures show the downslope movement of fan sediment due to gravitational processes. Pressure ridges were formed after the 


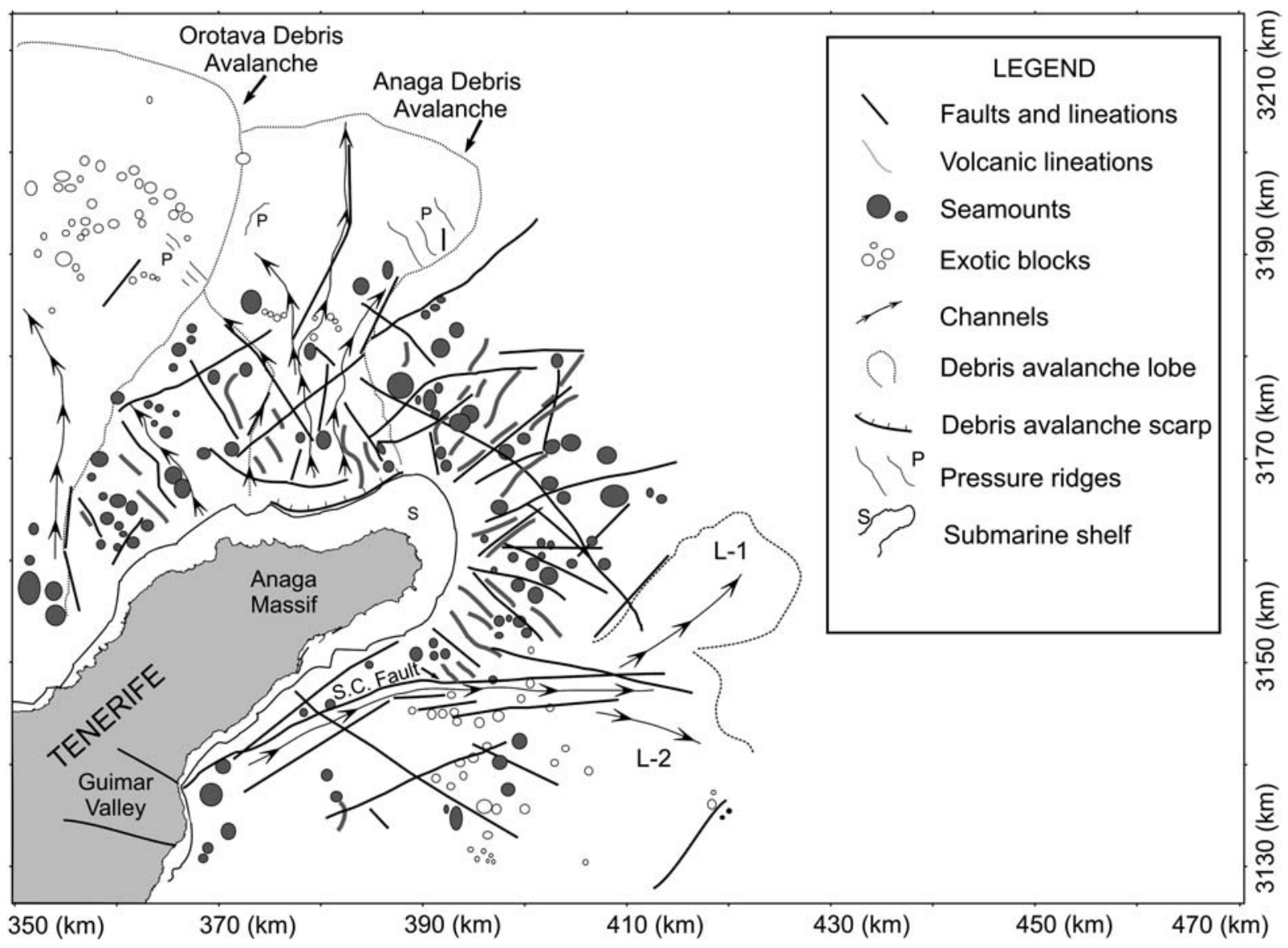

Figure 7. Morphological interpretation of Anaga surrounding flanks based on bathymetry data (bathymetry contour maps, slope maps, shaded relief maps and 3D images of bathymetry). The coordinates are Universal Transverse Mercator (UTM) Zone 28 distances in km. L-1 and L-2 show the locations of two lobes of the Güimar Debris Avalanche present on the study area. P shows location of shear and pressure ridges. S show location of the submarine erosive rocky shelf.

emplacement of the ODA, since they affect unconsolidated sediments. The length of these features varies between 27 and $182 \mathrm{~m}$, with a relief that varies from 5 to $30 \mathrm{~m}$ and a separation between them ranging between 830 and $1180 \mathrm{~m}$.

\section{Anaga Debris Avalanche (ADA)}

The new data have allowed us to map the real extension of the Anaga Debris Avalanche (ADA) (Figure 7). It is possible to differentiate two sectors of morphosedimentary significance associated to the ADA:

The proximal area of the ADA, where the collapse of the subaerial/submerged flank took place, starts with the Anaga landslide escarpment. This is not simple, being constituted by at least two scarps, which are identified in the 3D map (Figure 8). A broad entrant of $10 \mathrm{~km}$ length is recognised at $125 \mathrm{~m}$ relief, on the submarine shelf, that can reach $25-30^{\circ}$ of slope.
At $1250 \mathrm{~m}$ depth there is another entrant of $3.75 \mathrm{~km}$ length with a slope of $20^{\circ}$.

The sector extending from the abrupt area of scars to about $3000 \mathrm{~m}$ depth has a slope up to $10^{\circ}$. This sector represents the main channel of the debris avalanche. The width of the channel is 7000 to $10,000 \mathrm{~m}$, but its relief is difficult of evaluate, because it is very modified. We estimate relief between 25 and $115 \mathrm{~m}$. Mitchell et al. (2003) described how V-shaped channels can be seen formed around local highs with greater vertical relief in the flanks than lower down, which they consider consistent with the greater flow power of turbidity currents associated with the steeper gradient. These authors consider than the channels may have been active earlier in Anaga's history, and now the edifice base is an area of deposition rather than erosion. This is confirmed by low acoustic backscatter in sonar data (Masson et al., 2002). As the shelf 


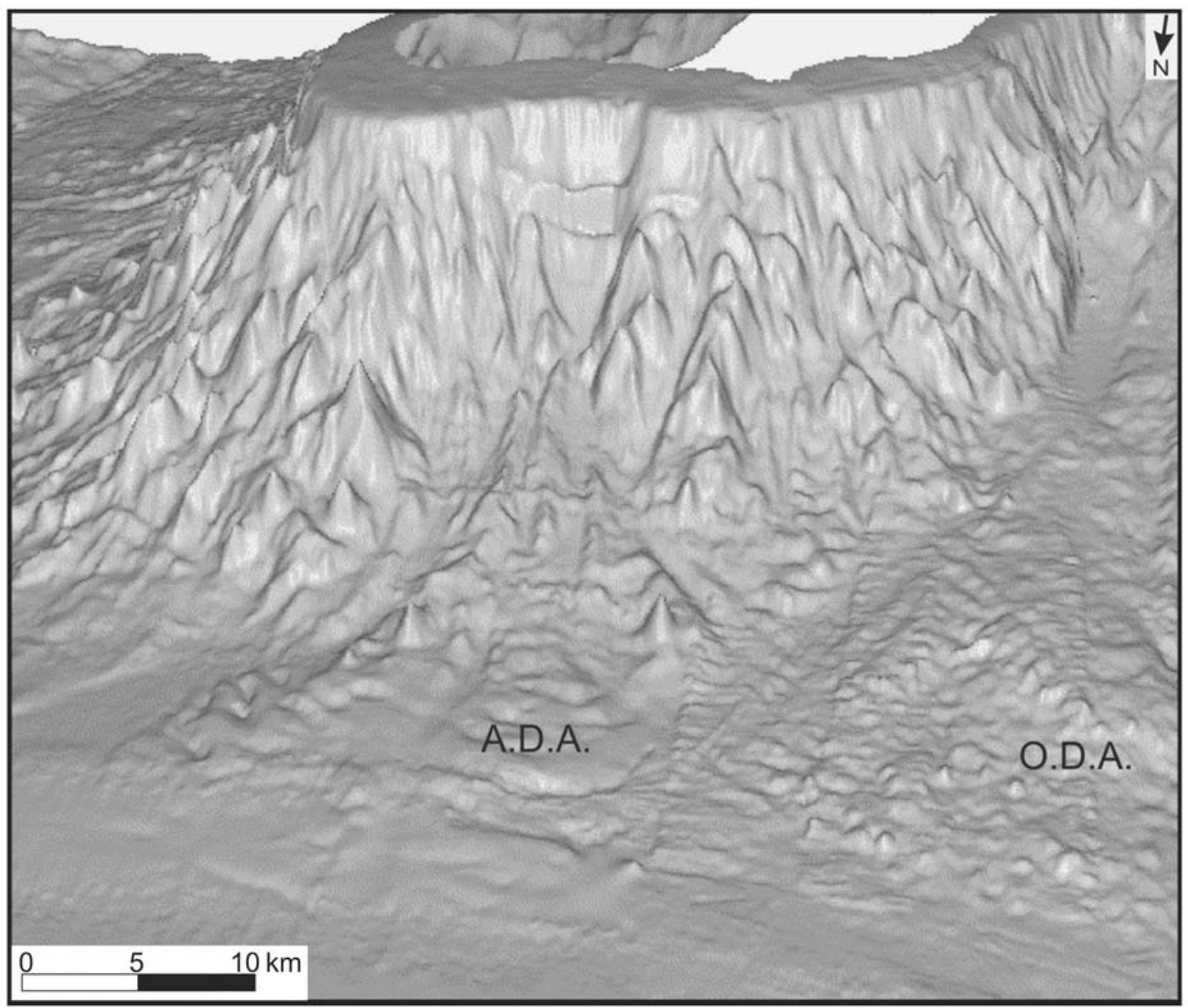

Figure 8. 3D image of Anaga north submarine flank showing the Anaga Debris Avalanche (ADA) and the Orotava Debris Avalanche (ODA). Scars of ADA are also recognised. View is from the NNW. Vertical exaggeration $\mathrm{x} 10$.

grew by coastal abrasion and subaerial erosion, the submarine canyons would have been progressively disconnected from their sources of hyperpycnal flows (Mitchell et al., 2003). Mitchell et al. (2002) studied the volcanic flanks of Tenerife, La Palma and El Hierro and found the bathymetric contours around Anaga more crenellated, its flank appearing more deeply gullied by erosion than the constructional flanks of $\mathrm{El}$ Hierro.

From our observations we found that these channels are frequently very linear and cut previous structures. We interpret many of them to be eroding tectonic lineaments.

The distal area of the ADA is characterized by the presence of the debris avalanche sediment apron.
Its deposits could be recognised to a maximum water depth of $3650 \mathrm{~m}, 45 \mathrm{~km}$ from the coast line. The deposit is defined by the convex shape of the isobaths on the bathymetric map and by their morphology in the digital elevation model (Figures 4 and 6).

Accurate estimates of debris avalanche volumes are difficult. Urgeles et al. (1999) noted that the base of debris avalanche deposits can only rarely be determined from seismic reflection profiles. That is why volumes are usually approximated from thickness maps created by comparing failed slopes with adjacent unfailed regions or, more simply, by assuming a mean deposit thickness over the area of the deposit. We think it is more reliable to use sediment thickness maps than to assume a mean deposit thickness. To calculate the 


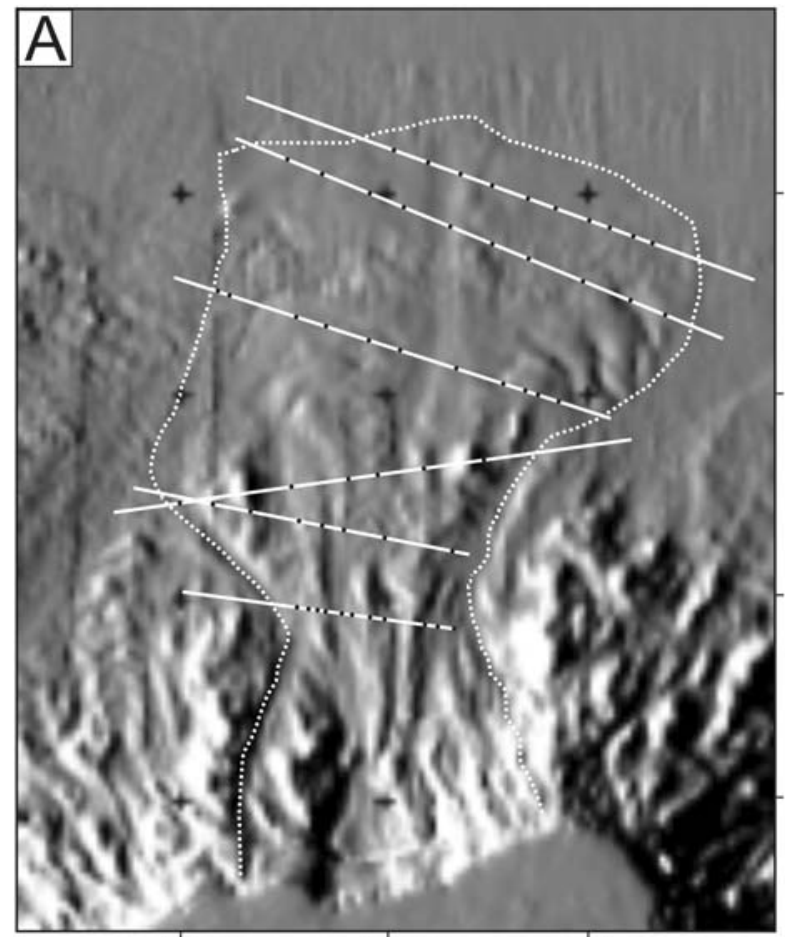

$370 \mathrm{~km}$

$380 \mathrm{~km}$

$390 \mathrm{~km}$

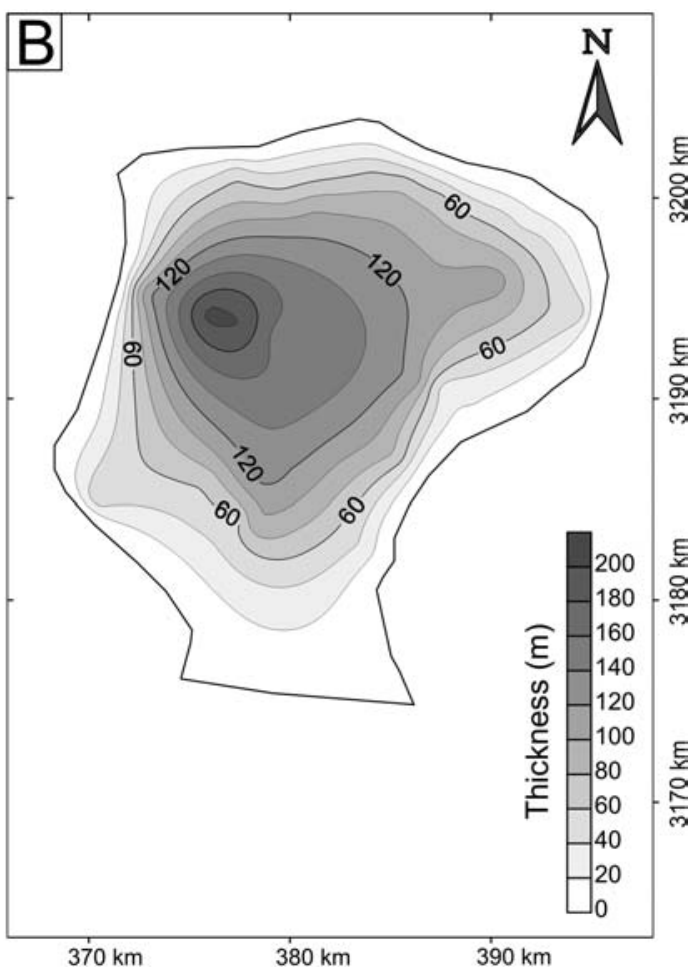

Figure 9. Panel A: Shaded relief bathymetric map of Anaga Debris Avalanche (ADA) area. White lines indicate the position of bathymetry profiles used for the thickness estimation. Black dots on the white lines are the points where the thickness of the avalanche has been estimated. Panel B: Thickness map of ADA. Thickness ranges between 0 and $220 \mathrm{~m}$. An area of $502 \mathrm{~km}^{2}$ for ADA deposits and a volume of $36 \mathrm{~km}$ have been estimated. The coordinates are Universal Transverse Mercator (UTM) Zone 28 distances in $\mathrm{km}$.

ADA volume, a thickness map was constructed using bathymetric profiles where the avalanche thickness was estimated in several points by comparing failed and unfailed slopes (Figure 9). A total volume of $36 \mathrm{~km}^{3}$ was obtained for the ADA, whose deposits are extended over an area of $502 \mathrm{~km}^{2}$. To establish this volume we did not consider the sediments placed at the avalanche's scarps or close to them, where erosion should be predominant. If there is sedimentation, it is difficult to quantify with geophysical methods due to the steep slope. At the northeast of the fan structure we have observed longitudinal pressure ridges (labelled $\mathrm{P}$, Figure 7). As mentioned above, these flow structures show the downslope movement of fan sediment due to gravitational processes and are formed after the emplacement of the ADA. The length of these features ranges between 3400 and $5000 \mathrm{~m}$. They have a relief that varies with a non-regular pattern from 3 to $38 \mathrm{~m}$ for the southern ones, and from 5 to $67 \mathrm{~m}$ for the northern ones. The separation between both sides is in the range of 1800 and $2800 \mathrm{~m}$.
Hernández Pacheco and Rodríguez Losada (1996) studied in detail the geology of the Taganana Arc onshore Tenerife, located to the north of Anaga Massif. The Taganana Arc, formed by an old dyke-swarm, which cut breccias and massive materials, is curved and concave to the north. These authors suggested that Taganana Arc could be part of an edifice extending in the past to the north of the present-day coast. They proposed that the activity of a major fault, possibly located to the north of the Taganana margin, was the origin of the dip of the old dyke-swarm formed by dragging and rotating the northern side of the Anaga Block. They observed that the flexure the dykes have suffered was caused by fault drag and related them with the collapse of a volcanic edifice that extended in the past to the north of the present-day coast. They also suggested the possible existence of a big normal fault (not-mapped) to the north of Anaga that lead to this collapse. Finally, Hernández Pacheco and Rodríguez Losada (1996) suggested that the collapse to the north of Anaga is still active today, as could be seen from the 
existence of modern normal faults, small slides, scree and other recent avalanche deposits.

Our data appear to support the idea suggested by Hernández Pacheco and Rodríguez Losada (1996) that Anaga has suffered one or more collapses to the north. If we look at the scar described above, it seems possible than more than one landslide happened in this area. On other hand, the fan structure of the ADA seems to be the result of a single event. It is also likely that different collapses happened to the north, the last being the bigger, burying older events. We do not have evidence of how many collapses happened in this area with our detailed bathymetric analyses, so that more detailed studies with low frequency seismic reflection in the area of the scars will be needed to resolve this question.

\section{Comparison between $O D A$ and ADA}

Our data confirms that the western boundary of the lobate deposits has been partially overlapped at its distal area by the ODA, as was suggested in previous works (Masson et al., 2002), which estimated an age of at least $600 \mathrm{ka}$ for the ADA.

Comparing both avalanches (ODA and ADA) we note that ADA has some different characteristics:

- The surface of the ADA sediment lobe presents less exotic blocks. This deficiency of blocks could indicate that they had been buried by younger sediments, but it also can be attributed to a longer exposure to erosion, to the kind of material involved in the event, or to other flow characteristics.

- Both the channel and the fan structure of ADA have a larger degree of modifications or erosion compared to the ODA. Also, in ADA we have recognized at least four isolated seamounts, with diameters 800 and $1700 \mathrm{~m}$, and heights between 140 and $350 \mathrm{~m}$. Their size and shape in the resolution of our data is enough to be differentiated from exotic blocks. Other authors studying the hummocky terrain in the channel between Gran Canaria and Tenerife (Krastel and Schmincke, 2002) interpreted the large, isolated blocks as volcanic morphologies and the large number of small highs concentrated in an area as exotic blocks. Our interpretation seems to fit well with the conclusions of Krastel and Schmincke. It is not so evident studying our data, if the blocks are intruding the avalanche, or if they were partially buried by it. The fact than the ADA has suffered more triggering processes and volcanic intrusions, seems to indicate an older age for the ADA, which subsequently has been affected by erosional processes for a long time.

- The pressures ridges found in ADA have maximum lengths of $5 \mathrm{~km}$, maximum relief of $38 \mathrm{~m}$ and a separation between them in the range of 1800-2800 m; while the ones in ODA, having a similar depth (as much as $30 \mathrm{~m}$ ) are less clearly seen due to their shorter length (less than $200 \mathrm{~m}$ ).

\section{South sector}

On the southeast coast of Tenerife, the dominant morphologic feature is the 'Cordillera Dorsal' (Figure 2), composed of a series of northeast trending ridges made of two flow series and separated by an unconformity. At the Cordillera Dorsal an 8-9 km wide valley was formed, with an amphitheatre-shaped head, an area of $73 \mathrm{~km}^{2}$ and prominent side walls. The origin of this Güimar Valley was interpreted by Navarro and Coello (1989) to be the result of landslide processes, the same origin as for the Orotava Valley (Figure 2). Geological studies of Güimar Valley showed that it was formed by a flank collapse younger than $0.83 \mathrm{Ma}$, the most recent age obtained for lava flows in the scarp (Ancochea et al., 1990).

South of Anaga offshore massif, the most significant feature is a continuous scarp that produces a very significant slope break, that can be clearly identified in a three-dimensional representation of bathymetry (Figure 10) and whose trace is represented in Figure 7. The scarp is limiting the southern edge of Anaga offshore structure along at least $50 \mathrm{~km}$, and its direction changes abruptly from $\mathrm{N} 68^{\circ} \mathrm{E}$ to almost $\mathrm{E}-\mathrm{W}$. Between 600 and $3375 \mathrm{~m}$ water depth there is a clear change in all bathymetric contours, coinciding with the scarp (Figure 4). There are some differences between the areas at both sides of the scarp. The area at the north side of the scarp corresponds to the Anaga submarine massif. It has an irregular morphology characterized by numerous pinnacles, ridges and gullies that have been mapped in Figure 7. In some places, these forms are cut with a narrow and linear shape, indicating structural control. Submarine channels and canyons seem to exploit these tectonic directions. The area to the south side of the scarp has less slope, ranging from 0 to $5^{\circ}$ (Figure 5) and is topographically smooth. The surface of this area has rough topography, similar to that of the ODA, with the presence of many small topographic highs, both pinnacles and perhaps exotic blocks. In the shallower part of the scarp along almost $30 \mathrm{~km}$ of the trace, there is a steep slope that varies 


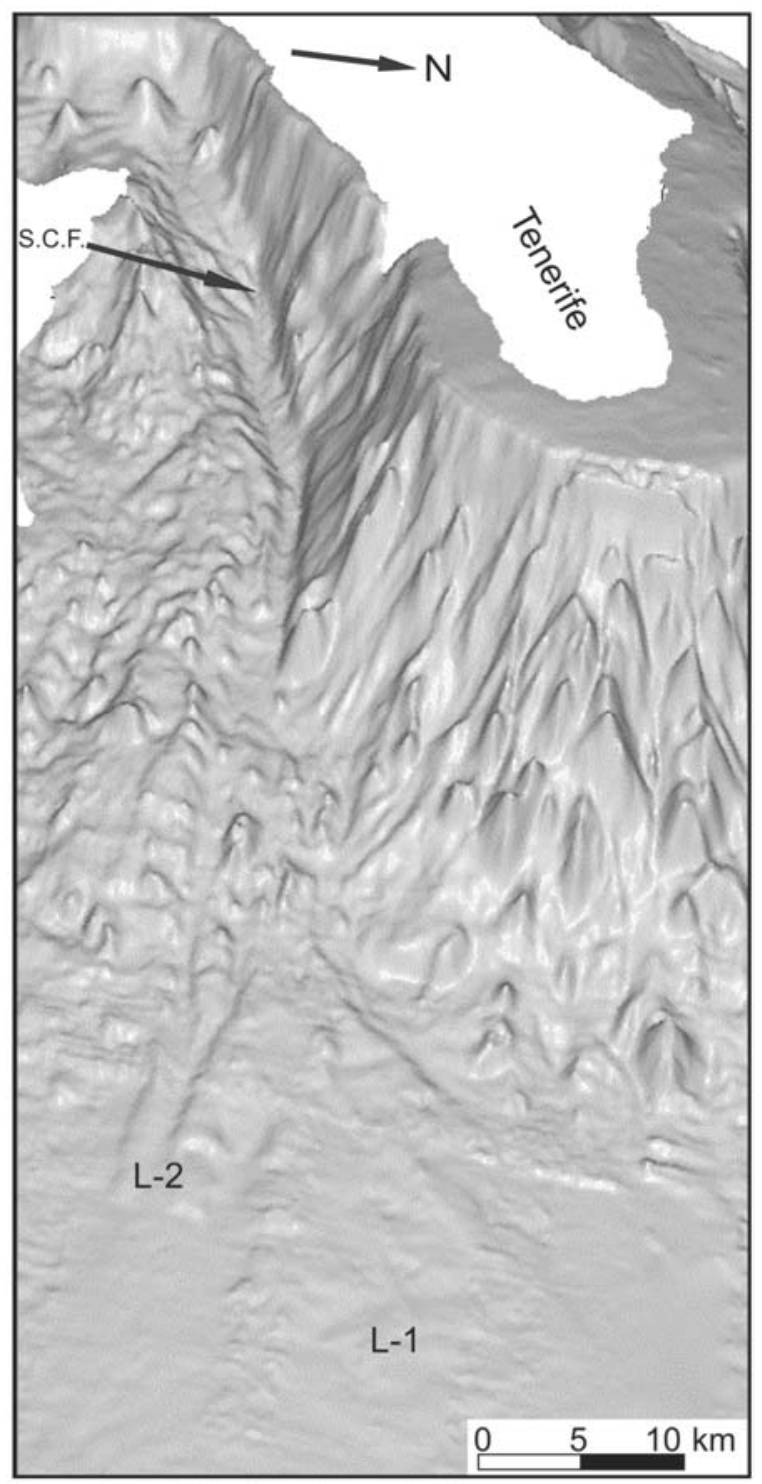

Figure 10. 3D image of Anaga SE submarine flank showing the Santa Cruz Fault and two lobes of Güimar Debris Avalanche (L1 and L2). View is from the ENE. Vertical exaggeration $\mathrm{x} 10$.

between $25^{\circ}$ and $40^{\circ}$, but reaching slopes of $55^{\circ}$ (Figure 4). In contrast, in the deepest part of the scarp, along $20 \mathrm{~km}$, the slope decreases to $5-10^{\circ}$.

From the morphological observation of this scarp it is controversial whether it was created by sedimentary or tectonic processes or a combination of both. The origin of the steep escarpments bounding the seawardfacing embayment in the Canaries has been the subject of different interpretations, since its first association with gravitational processes by Bravo (1952). Nowadays it is accepted that giant landslides are a common feature in the Canary Islands and the relation between giant landslides and straight-walled valleys, calderas and wide coastal embayments, has been found onshore (Ancochea et al., 1990; Ancochea et al., 1994; Carracedo 1994; Guillou et al., 1996) and offshore (Watts and Masson, 1995; Teide Group, 1997; Masson, 1996; Urgeles et al., 1997; Carracedo, 1999, Mitchell et al., 2002; Mitchell et al., 2003, Masson et al., 2002 and Acosta et al., this issue). In Figure 7 the geographical position of the onshore Güimar's Valley scarp has been plotted, as well as the trace of the scarp found offshore. Looking at the coincidence of both features we could attribute the origin of the scarp entirely to the landslide process of the Güimar Debris Avalanche, being a continuation offshore of the eastern sidewall of this avalanche on land. Such an interpretation was suggested by Masson et al. (2002) for the sidewalls of El Golfo Debris Avalanche on El Hierro island. But a sedimentary origin for the submarine scarp without involving structural process can be argued. Observation of the relations between the amphitheatres and the scarps in other debris avalanches of the Canary Islands, such as the ones in El Hierro, La Palma, Tenerife and Gran Canaria islands, reveals that usually the head amphitheatre of the debris avalanche is aligned normal to the downslope direction of movement of the avalanche (for references see Masson et al., 2002; Acosta et al., this issue). Here the offshore scarp is not aligned with the direction of the onshore scarp, but instead is deviated from that direction by $55^{\circ}$ to the north (Figure 7). Looking at the scarps of Güimar Valley on land, it seems obvious that if an avalanche happens in the absence of a tectonic stress, it would create an offshore scarp following more or less a straight direction with the onshore one, or having a gentle turn due to the regional bathymetry, as happened in some of the landslides in Hawaiian islands (Moore et al., 1989). The sharp angle of continuation between both scarps seems to indicate than the debris avalanche must have changed its direction sharply when it reached the coast of the island if the scarp was formed from the carving of the avalanche flow.

Faulting has been recognized as one of the factors that can directly cause or contribute to the occurrence of giant landslides. Day et al. (1999) described the well developed topographic San Andrés fault scarp on the flank of the steep-side NE rift of El Hierro, and related it to an aborted giant collapse; Vidal and Merle (2000) used a model to prove that the reactivation of a vertical fault in volcanic cones generates normal faults and an upturning of the layers that induces a 
flank collapse. In Hawaii, the Hilina slump has been recognized as an active landside that breaks the mobile southeast flank of Kilauea volcano and is headed on land by a system of seaward facing normal faults (Morgan et al., 2003). From the study of the characteristics of this scarp, its relation with the on-land features of Güimar Valley and the comparison with other avalanches in the Canaries, we suggest that a tectonic process seems to have created the scarp. Whether the fault scarp was created during on avalanche or before it remains unsolved, but the stress regimen in this area could have been the cause of the debris avalanche process on the buttressed flank of Tenerife. A submarine canyon has carved the sediments following the linear layout of the fault scarp. This canyon was also recognized by Krastel et al. (2001) and Krastel and Schmincke (2002), who mapped the Güimar Scarp on land but didn't interpret a debris avalanche scarp offshore.

In the absence of seismic lines transverse to the scarp, its origin remains unsolved and therefore we can interpret it as a fault. Future studies will be needed to solve the fact that Güimar Debris Avalanche seems to be a particular case among all others previously studied in the Canary Islands. Since it is the first time that this scarp is described and interpreted as a fault, we have called it 'Santa Cruz Fault Scarp', because the town of 'Santa Cruz de Tenerife' is the nearest main geographic place on land.

\section{Güimar debris avalanche (GDA)}

At a water depth of 3200-3300 m the sea-floor has a 0 to $5^{\circ}$ slope. In this area there is an important accumulation of sediments that forms a deposit of $20 \mathrm{~km}$ length and $12 \mathrm{~km}$ width that has been mapped as L1 in Figure 7. Adjacent to this lobe to the south, another fan-shape structure has been recognised with a length of $8 \mathrm{~km}$ and a width that can not be exactly defined because it extends beyond the studied area limit (L2 in Figure 7). The thickness of these lobes varies between 5 and $15 \mathrm{~m}$ for L1 and 5 and 10 for L2. Hummocks can be recognized in the digital model elevation (Figure 6) and in the detailed bathymetric map. Because of the fan shape structure and the existence of the block field terrain, we interpret these deposits as products of a debris avalanche. Some of these topographically isolated highs seem to be volcanic cones rather than blocks transported by the debris avalanche, but distinction between them has not been possible, as there are no clear criteria to differentiate them. So, although it seems clear that this area is covered with the deposits left by a debris avalanche, some volcanic morphology may also be present. These fans can be seen in the digital model elevation (Figure 6) and the three-dimensional representation of bathymetry (Figure 10).

Our data indicate that the fans are the northern deposits of the Güimar Debris Avalanche. The total extension of the avalanche in Gran Canaria-Tenerife channel has been mapped by Krastel and Schmincke (2002) and by Acosta et al. (this issue). They interpreted Güimar Valley as the source area for the avalanche deposits of this area, and our results point to the same conclusion. These authors also recognized from backscatter data a large number of individual hummocks of different sizes and they discussed their nature, concluding that most of them are exotic blocks, although some, usually located close to the islands, are volcanic cones.

\section{Anaga offshore distal region}

\section{Sedimentary characteristics}

Topographic parametric sonar seismic profiles have been the basis for studying the Anaga offshore distal region, because bathymetric data in this area presents numerous artefacts (see Figure 4) that cannot be removed by standard processing.

The area beyond the $3500 \mathrm{~m}$ bathymetric contour is called the Anaga offshore distal region. From this contour, the slope stabilizes to less than $5^{\circ}$, resulting in a more or less flat seafloor, where depths range from 3500 to $3700 \mathrm{~m}$, which are the maximum values northwest of Anaga. Seismic profiles show parallel and continuous reflectors (Figure 11) that characterize the distal region offshore Anaga Massif as a typical area of deep oceanic hemipelagic sedimentation. In the more distal region, the parametric system recorded a maximum of $0.12 \mathrm{sec}$ (two way travel time). If we assume a velocity for marine sediments in $\mathrm{Ca}$ narian Archipelago of 1.7-2.1 km/sec. (Dañobeitia and Canales, 2000), this implies a total thickness of $102-126 \mathrm{~m}$.

In the studied seismic sequence we have selected four reflectors (named R1, R2, R3 and R4) to show the interpretations. We choose these because of their presence in most of seismic profiles. Although there were some stronger ones, they have less continuity along the profiles.

Taking into account the nearest deep ocean drill sites to our study area we can deduce a very similar 


\begin{tabular}{|l|l|l|}
\hline SEISMIC FACIES & DISTRIBUTION & INTERPRETATION \\
\hline Parallel & Deep areas & Deep sea pelagic sedimentation \\
\hline Chaotic & Ubiquitous & $\begin{array}{l}\text { Large scale mass movement } \\
\text { High quantity of sedimentation of island provenance } \\
\text { Deformation caused by intrusive bodies }\end{array}$ \\
\hline Transparent & Ubiquitous & Muddy strata seismically homogeneous \\
\hline
\end{tabular}

Figure 11. Seismic reflection facies defined in this study and their geologic interpretation.

composition for the material that forms the parallel and continuous reflector seismic sequence observed in profiles. Therefore, we used Ocean Drilling Program (ODP) Sites 953 and 954, located to the north and northeast of Gran Canaria (Figure 3), which reveal the lithological composition of the sediment in this area. In both sites, the first hundred metres corresponds to Unit I and are constituted by Holocene to upper Pliocene (0-3 Ma) sediments, consisting dominantly of pelagic clayey, nannofossil ooze and graded nannofossil clay-silt, with lesser amounts of foraminifer sands, lithic crystal sands, and silts. Coarse sands, rich in neritic biogenic material, recovered in the upper $100 \mathrm{~m}$ have been interpreted by Schmincke (1995) as turbidites possibly related to glacially controlled changes in sea level. The minor, thin fallout tephra layers at these sites were probably erupted on Tenerife and may represent the outer part of larger fallout fans (Schmincke et al., 1995). In this way, we can consider that the lithological composition in the Anaga offshore distal region may not differ too much of the one drilled on north margin offshore Gran Canaria.

Five distinct seismic facies are identified based on seismic reflection character and geometry. Environment interpretation of each seismic facies has been made based on Mitchum et al. (1977) (Figure 11). The detailed analysis of all the seismic profiles shows clearly the influence of Tenerife island. To the western edge of the seismic profiles the above mentioned reflectors are not recognized. The seismic sequence 

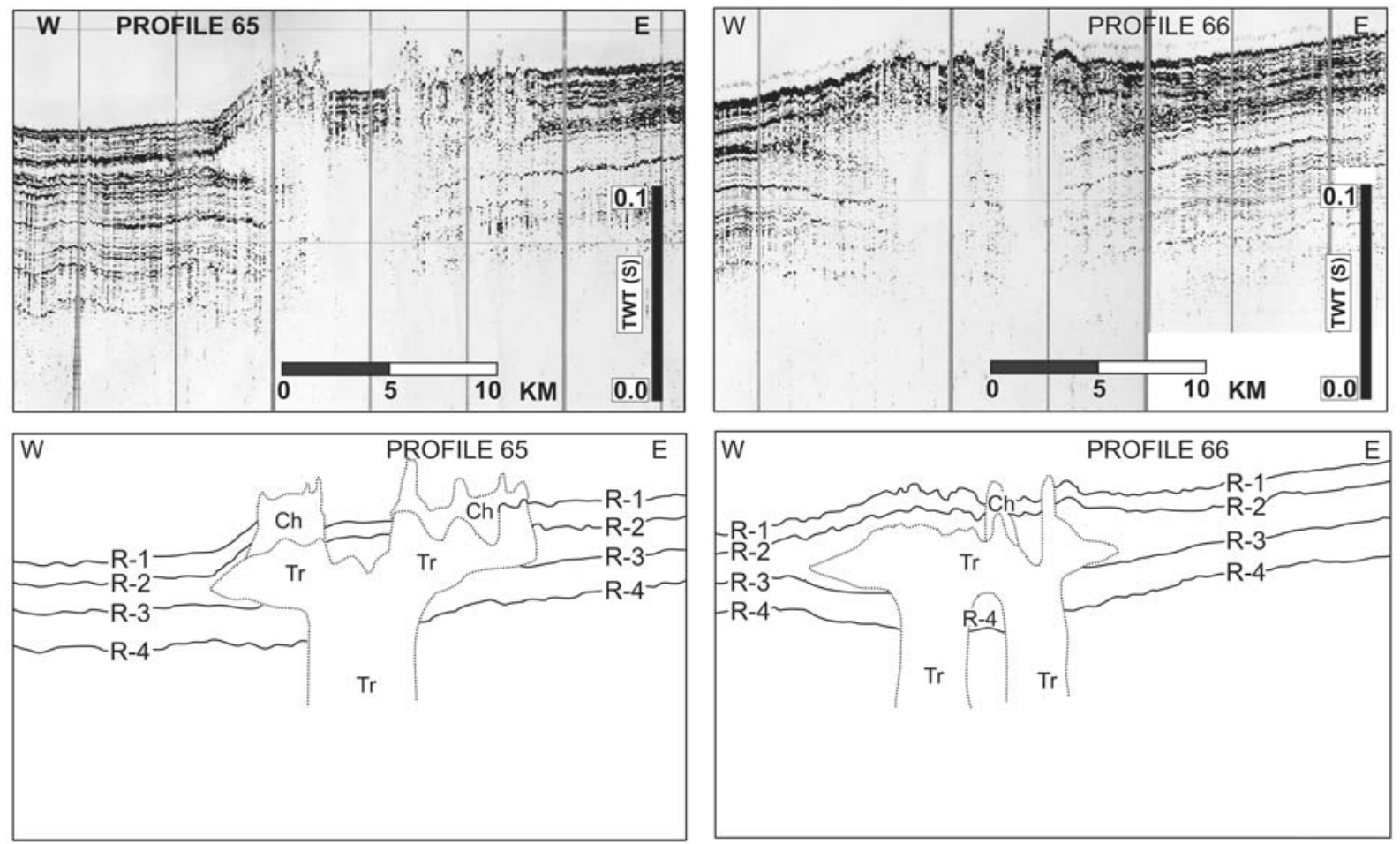

Figure 12. Interpreted parts of Profiles 65 and 66 showing two intrusive bodies of transparent facies (Tr) that cut parallel and continuous sequences. Location of the seismic profiles and the intrusive bodies are placed in Figure 3. Selected reflectors for this study are shown as R-1, R-2, R-3 and R-4 and chaotic facies as Ch. There is not enough evidence to interpret the volcanic or sedimentary origin of the intrusions.

loses its parallel and continuous aspect to show a more chaotic sequence nearer to the island. As the sequence is closer to the island, there is more volcanoclastic material mixed with the deep sea pelagic sediments. Bottom currents also affect the sediments, as has been reported in other areas of the Canaries, such as the channel between Gran Canaria and Fuerteventura, in which sediments are entirely modified by erosional currents (Funck and Lykke-Andersen, 1998), or the channel between Tenerife and Gran Canaria, where Teide Group (1997) recognized sediments whose internal morphology suggested deposition under the influence of bottom currents, probably the North Atlantic Deep Water at a depth of 1500-3900 m.

The Seismic sequence is interrupted in the distal area by an intrusive body. Continuity of the parallel facies of Profiles 65 and 66 ends sharply, as can be seen in Figure 12. Transparent facies material intrudes the sequence with one root in Profile 65 and two roots in Profile 66. These roots seem to be the conduits that fed the intrusive bodies. Both of them have a general oval shape, but in the shallow subsurface it turns more irregular with the intrusive material cutting the sediments that lie above. We have not enough criteria to distinguish if the transparent facies material is of volcanic or sedimentary origin.

\section{Structural characteristics}

TOPAS Profiles 51, 68, 67 and 66 show the structural complexity typical of an area proximal to a volcanic island. Numerous faults have been distinguished. In some areas these faults are separated from other tectonic structures by great distances, but there are also some areas where fracture density is higher and we found others faults every hundreds of metres or every few kilometres. This occurs along the western edge of Profile 67, where we recognized four faults over ten kilometres (Figure 13). The undulating reflector pattern in this region, indicating deformation, could be the result of the same tectonic process that generated the faults. The lack of penetration in this ultra-high resolution profile does not allow us to discern between these two possible mechanisms.

Among all the identified fractures, there is one that is noteworthy because of its particular characteristics, called the 'Guayotá Fault'. This fault has been recorded on seismic Profiles 51, 68, 67, 66, 65, 64 and 

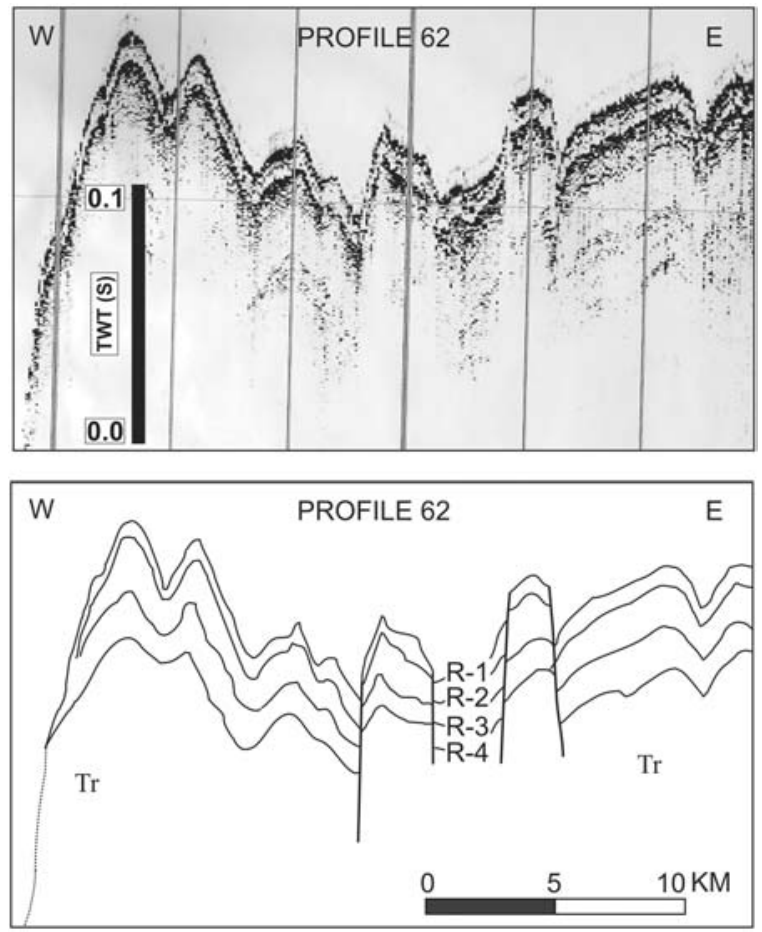

Figure 13. Interpreted segment of seismic Profile 67 showing a high fracture density. The undulated reflector pattern could be the result of the same tectonic process that generated the faults, or could be deformation caused by an igneous intrusion process, as transparent facies are seen below. Lack of penetration in this ultra-high resolution profiles does not allow us to discern between these two possible genesis mechanisms. Location of the seismic segment is shown in Figure 3.

62 , in a north to south order, and as the profiles are separated by $10 \mathrm{~km}$, its total length appears to be at least $60 \mathrm{~km}$ (Figure 3). It can be seen that the fault affects at least 100 metres of the more recent sediments, but as we do not have enough penetration, it is not possible to evaluate the actual depth extent of the fault. Additional seismic data is needed to provide a real estimate of the thickness of materials that have been affected by the fault and if they reach the basement or not. The Guayotá Fault is oriented N-S along its north edge, among seismic Profiles 51, 68, 67 and 66; and after an inflexion between profiles 66 and 65 it takes a direction of NW-SE, in profiles 65,64 and 62 (Figure 3).

Figure 14 shows the segments of the seven profiles where the fault appears. The Guayotá Fault is a compressive structure with an offset varying between 25 and 30 metres. Because of the morphology seen in the profiles and the orientation that it presents we suggest that it is a contractional strike-slip fault.
Two of the profiles do not show a vertical offset. As they are the northern and southern ones and they probably indicate the limits of the fault. In Profile 51 the fault is recognized as a deformation area, but the vertical offset between the reflectors cannot be observed. In Profile 62 the fault is recognized by the abruptly disappearance of the reflectors, but again there is no offset, nor deformation in the upper area of the seismic sequence.

\section{Structural analysis}

\section{Methodology of the structural analysis}

Structural data are required to understand the complex regional context of the Canary Islands, but there are very few structural studies. Field structural data have been taken and interpreted on Fuerteventura by Stillman (1987) and Fernández et al. (1997), in Lanzarote by Marinoni and Pasquarè (1994) and in La Palma by Fernández et al. (2002).

Numerous faults have been observed in the Anaga offshore region (Figure 7). Interest in knowing which the prefered structural directions are, guided us to carry out a structural analysis. Previous analysis of the topography of the region (Mitchell et al., 2003) did not find faulting to be an important process in the evolution of this area. However we find that erosion is often taking place along existing structural directions.

Submarine faults were mapped by bathymetric maps contoured at different values. Slopes maps and digital elevation models have been used. The software we used has allowed us to do many tri-dimensional models that validate the interpretations. In the bathymetric maps, faults have been distinguished by the sharp inflexion produced in successive contours by faults. In the slope maps tectonic gradients have very clear slope contrasts. In the digital elevation models, faults are recognised as in aerial photographs by shadow changes, and also because they cut previous structures like volcanic lineations, channels and debris aprons. This kind of model helped us to distinguish faults that could not be identified in bathymetric and slope maps. The combined study of bathymetric maps, slope maps, three-dimensional models and digital elevation models is the best method to recognise submarine faults in a map.

To quantify the preferred fractured direction all the interpreted structures have been georeferenced, and 

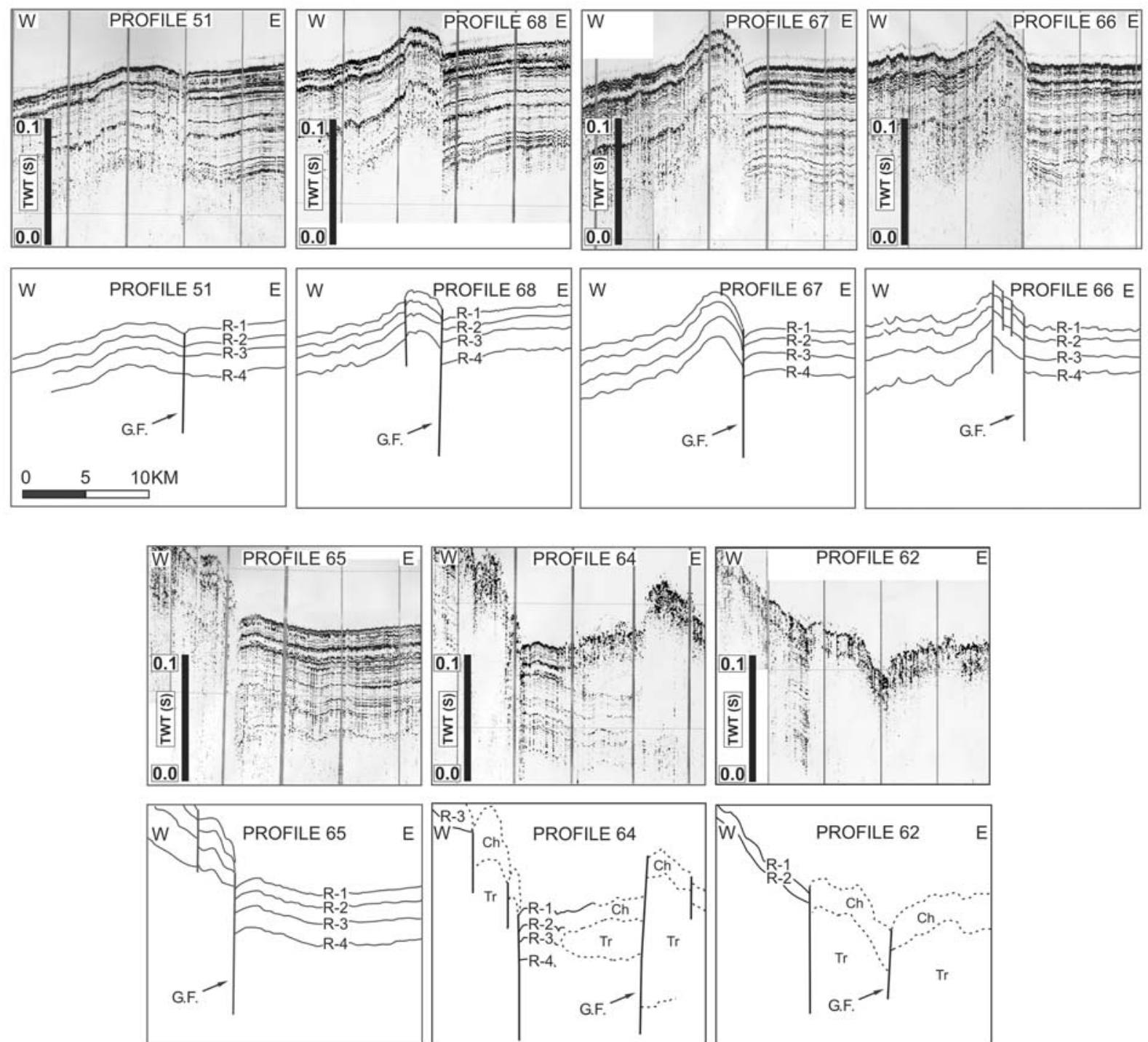

Figure 14. Interpreted seismic reflection Profiles 51, 68, 67, 66, 65, 64 and 62 showing the Guayotá Fault. Location of the seismic profiles and the interpreted fault are placed in Figure 3. The fault is affecting at least 100 metres depth of the more recent sediments. Its total length in a ground plan appears to be at least $60 \mathrm{~km}$. Guayotá Fault direction is N-S in its north edge, among seismic Profiles 51, 68, 67 and 66; and after an inflexion between Profiles 66 and 65 it takes a direction of NW-SE in Profiles 65, 64 and 62. It is a compressive fault with an offset varying between 25 and 30 metres. We suggest that the Guayotá Fault is a contractional strike-slip fault.

when a fault changes its direction one or more times, we must consider these changes segmenting this lineation in more than one (Fault map in lower panel of Figure 15). For the structural analysis we assign a proportional weight to the fault trace length.

\section{Results of the structural analysis}

A total population of 63 fault segments is represented in a rose diagram with an interval class of $15^{\circ}$ (Fig- ure 15). Almost all directions are represented, showing a radial pattern typical of areas where extension of crustal layers occurs because of the intrusion of magma bodies or other kinds of domes. Faults are recognized radiating from the center, as they align in the direction perpendicular to the direction of maximum tension (Twiss and Moores, 1992; Ramsay and Lisle, 2000). Radial patterns have been previously identified in oceanic islands in fractures and dykes. Examples are found in the Canaries: like the ones 

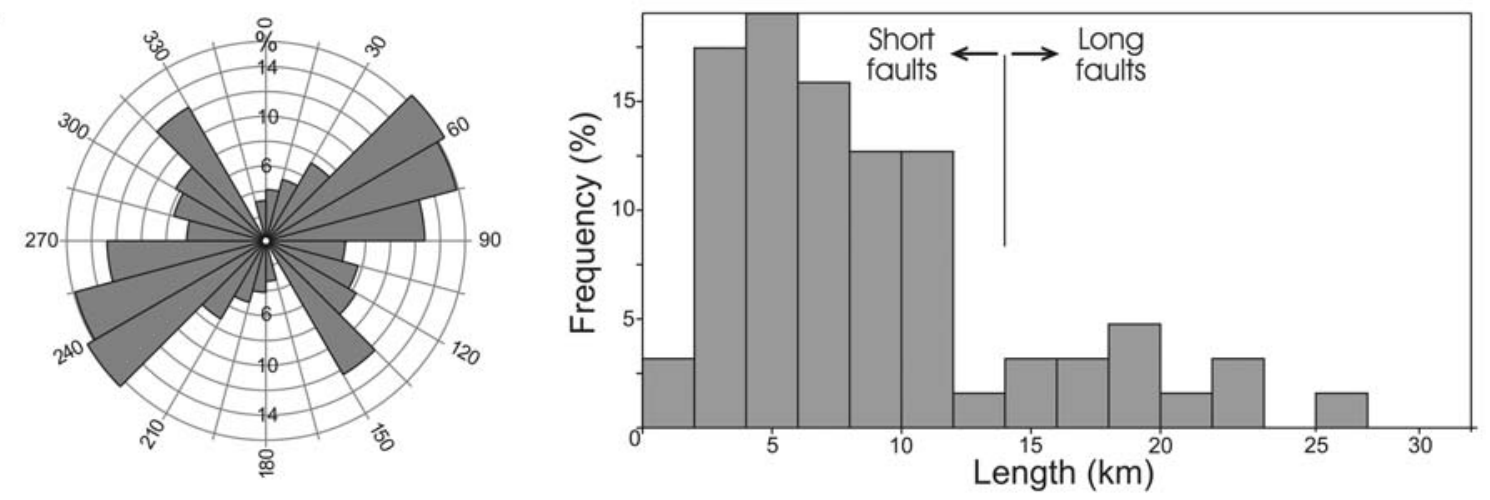

B

\section{0-14 km FAULT LENGTHS}

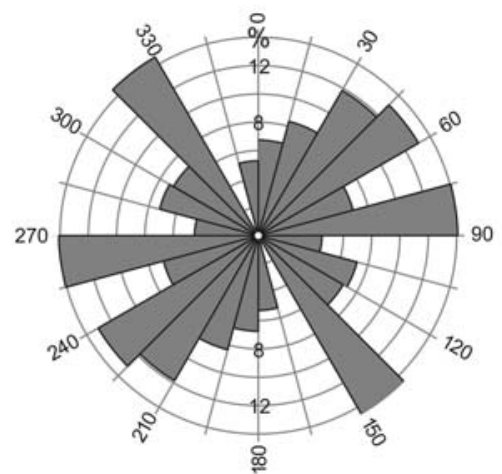

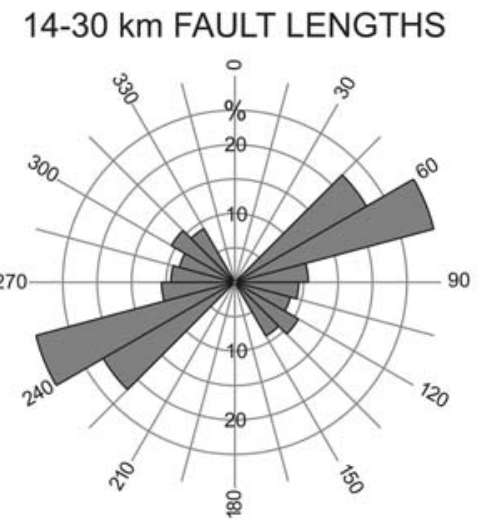

FAULT MAP

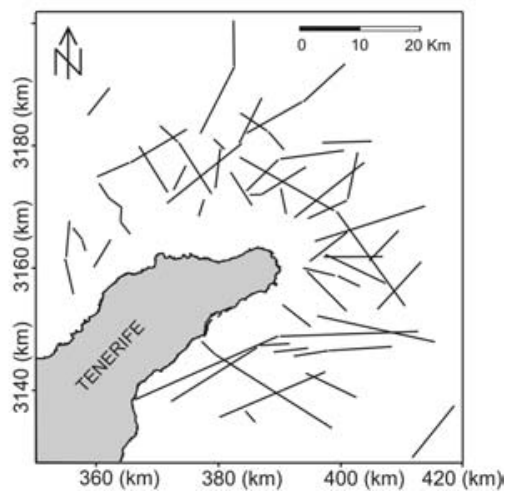

Figure 15. Panel A: Total fault length rose diagram and fault length distribution histogram. Panel B: Rose diagram for faults lengths between 0-14 km, rose diagram for faults lengths between $14-30 \mathrm{~km}$, and the fault map used in the structural analysis. The coordinates are Universal Transverse Mercator (UTM) Zone 28 distances in $\mathrm{km}$.

reported in Fuerteventura (Ancochea et al., 1996; Stillman, 1999), Tenerife (Ablay and Martí, 2000) or La Gomera (Ancochea et al., 2003); as well as in other archipelagos like Cape Verde (Day et al., 1999) or the Society Islands (Blais et al., 2000).

Further more, two major structural directions are recognized: The main one is NE-SW, with its conjugate at $90^{\circ}$, NW-SE, being the second in importance. The NE-SW submarine direction matches with the Tenerife direction in the Anaga Massif area and Cordillera Dorsal, clearly indicative of the importance that structural control has in the growth of oceanic island.

The interpreted faults have been analyzed as a function of length. Two modal values appear, allowing us to separate two populations of faults: The short ones less than $14 \mathrm{~km}$, and the long ones for faults between 14 and $30 \mathrm{~km}$. We can conclude that for the shorter faults the same radial pattern is recognised, although there are three preferred directions: Two of them were the same as seen in the general rose diagram, NESW and NW-SE, but an E-W direction also emerges. While in the shorter faults a radial pattern is recognized, when studying the longer faults the results point to a more defined pattern in a NE-SW direction.

Our results have been compared with structural field analysis undertaken on the Anaga Massif (Marinoni and Gudmundsson, 2000), where three main directions were obtained. Two of them, NW and NE, coincide roughly with the main axial trends of Tenerife, while another E-W trend does not correspond to the main axes of Tenerife, or with the rift-zone trends proposed by Carracedo (1994). Instead, it correlates with one of the major tectonic trends of the Canarian region, which consists of E-W structures (Banda et al., 1981: Marinoni and Pasquarè, 1994). 
Structural analysis of the submarine fractures shows a good correlation with the main directions obtained in the Anaga onshore region.

\section{Conclusions}

The morphology of Anaga submarine slopes are partly a result of the volcanic terrain being reshaped by mass wasting and faulting. Bathymetric and TOPAS seismic data collected around the peninsula of Anaga have increased our understanding of the growth and destruction of Tenerife and oceanic islands in general. 1. The offshore Anaga Massif starts with a submarine shelf, a consequence of wave erosion during Pleistocene glacially induced regressions. Volcanic morphologies, faults that cut previous structures, and the results of mass wasting movements associated with slope failures can be recognized in the submarine Anaga structure. Below the $3500 \mathrm{~m}$ contour the slope stabilizes to less than $5^{\circ}$ in a more or less flat topographic seafloor, being deepest NW of Anaga.

2. An area of $502 \mathrm{~km}^{2}$ and a debris volume of $36 \mathrm{~km}^{3}$ characterize in the ADA (Anaga Debris Avalanche). The presence of various scars shows that Anaga could suffer several collapses to the north, as also suggested by Hernández Pacheco and Rodríguez Losada (1996) studying the Taganana Arc geology onshore Tenerife. Our data confirm that the western boundary of the lobate deposits has been partially overlapped at its distal area by the ODA (Orotava Debris Avalanche), as suggested in previous works (Masson et al., 2002) which indicated an age of at least $600 \mathrm{ka}$ for the ADA. Comparison between ODA and ADA also point to an older age for ADA, since more erosive processes and volcanic intrusions have affected both the channel and the fan structure. Moreover, ADA has less exotic blocks than ODA, due to burial by younger sediments.

3. Bathymetric data support the existence of many volcanic morphologies, between 1000-3000 m across and 100-200 m high around Anaga submarine massif. They could be related to dyke activity radiating from a central volcanic zone. In some areas distinction between volcanic morphologies and exotic blocks from avalanches is difficult and in the absence of other data there is no evidence to make a distinction.
4. An intrusive body of transparent facies has been seen in two seismic profiles interrupting the parallel facies of the seismic sequences in these areas. They have one and two roots respectively that acted as conduits feeding the intrusions. We do not have enough criteria to distinguish if the transparent facies material is of volcanic or sedimentary origin.

5. Numerous faults have been interpreted and represented from the new data. Most of them were recognized by the combined study of bathymetric maps, slope maps, tri-dimensional models and digital elevation models. They have been used to do a structural analysis. Two of the larger structures recognized have been called 'Santa Cruz Fault' and 'Guayotá Fault':

- 'Santa Cruz Fault' was recognized in the bathymetric data limiting the southern edge of Anaga offshore structure along at least $50 \mathrm{~km}$. Its direction changes sharply from $\mathrm{N} 68^{\circ} \mathrm{E}$ to almost E-W.

- 'Guayotá Fault' was recognized in seismic profiles at the NE distal area of Anaga along $60 \mathrm{~km}$ of strike. Guayotá Fault is a compressive structure that affects at least $100 \mathrm{~m}$ of sediments with a 25-30 m offset in a direction that changes N-S to NW-SE towards the south. We interpret it as a transpressional strike-slip fault.

6. From the analysis of all the submarine faults directions that have been interpreted, we found a radial pattern typical of oceanic islands. Besides this typical pattern, three main directions are emphasized in the rose diagrams: NE-SW, NW-SE and E-W. The main orientation, NE-SW, matches the Tenerife direction for the Anaga Massif and Cordillera Dorsal, and is also the one that controls the longer faults. There is good correlation with the main directions obtained in the Anaga onshore region by previous authors.

7. Faulting has been recognized as a key process for the occurrence of debris avalanches and the growth of volcanic lineaments. Moreover, faulting is modifying previous structures and channelling the flows. Submarine faults are more difficult to study compared with those onshore because of the environment in which they are located, but is important to quantify submarine faults as far as possible, as submarine flanks represent a major part of a given oceanic island. 


\section{Acknowledgements}

This work was funded by the ZEE project (Oceanographic and Hydrographic Research of the Spanish Economic Exclusive Zone) and the 'Universidad Complutense de Madrid'. We are grateful for predoctoral grant to Pilar Llanes coming from the 'Conserjeía de Educación de la Comunidad de Madrid y Fondo Social Europeo'. We also thank the captain, officers and crew of B.I.O. Hespérides in cruise ZEE-99 for their cooperation at sea. Comments by G. De Vicente, from Universidad Complutense de Madrid, have greatly improved the structural analysis. Thoughtful reviews by Douglas G. Masson and Hans-Ulrich Schmincke were invaluable in preparing the final manuscript.

\section{References}

Ablay G.J., J. Martí, Stratigraphy, structure, and volcanic evolution of the Pico Teide-Pico Viejo formation, Tenerife, Canary Islands, J. Volcanol. Geotherm. Res., 103, 175-208, 2000.

Abratis M., H.U. Schmincke, T.H. Hansteen, Composition and evolution of submarine volcanic rocks from the central and western Canary Islands, Int. J. Earth Sci., 91, 562-582, 2002.

Acosta J., C. Palomo, E. Uchupi, A. Munoz, J. Escartin, P. Herranz and J.L. Sanz, Morphology and seismic character of north slope of Tenerife, Canary Island. Evidence for episodic massive landslides, J. Geophys. Res., 102, 20325-20342, 1997.

Acosta J., E. Uchupi, A. Muñoz, P. Herranz, C. Palomo, M. Ballesteros and ZEE Working Group, Geologic evolution of the Older Canary Islands: Lanzarote, Fuerteventura, Gran Canaria and La Gomera, with a Brief description of the avalanches on the Younger Islands: Tenerife, La Palma and El Hierro, Mar. Geophys. Res., This issue.

Ancochea E., J.M. Fúster, E. Ibarrola, A. Cendrero, J. Coello, F. Hernan, J.M. Cantagrel, and C. Jamond, Volcanic evolution of the island of Tenerife (Canary Islands) in the light of new K-Ar data, J. Volcanol. Geotherm. Res., 44, 231-249, 1990.

Ancochea E., F. Hernán, A. Cendrero, J.M. Cantagrel, J.M. Foester, E. Ibarrola and J. Coello, Constructive and destructive episodes in the building of a young oceanic island, La Palma, Canary Islands, and genesis of the Caldera de Taburiente, J. Volcanol. Geotherm. Res., 60 (3-4), 243-262, 1994.

Ancochea E., J.L. Brändle, C.R. Cubas, F. Hernán, M.J. Huertas, Volcanic complexes in the eastern ridge of the Canary Islands: the Miocene activity of the island of Fuerteventura, J. Volcanol. Geotherm. Res., 70, 183-204, 1996.

Ancochea E., J.L. Brändle, M.J. Huertas, C.R. Cubas and F. Hernán, The felsic dikes of La Gomera (Canary Islands): identification of cone sheet and radial dike swarms, J. Volcanol. Geotherm. Res., 120, 197-206, 2003.

Banda E., J.J. Danobeitia, E. Surinach and J. Ansorge, Features of crustal structure under the Canary Islands, Earth Planet. Sci. Lett., 55, 11-24, 1981.

Blais S., G. Guille, H. Guillou, C. Chauvel, R.C. Maury and M. Caroff, Géologie, géochimie et geochronology de l'île de
Bora Bora (Société, Polynésie francaise), Earth and Planetary Sciences 331, 579-585, 2000.

Bravo T., Aportación al studio geomorfológico y geológico de la costa de la fosa tectónica del valle de la Orotava, Bol. R. Soc. Esp. Hist. Nat., Tomo L, 1-30, 1952.

Cantagrel J.M., N.O. Arnaud, E Ancochea., J.M. Fúster, and M.J. Huertas, Repeated debris avalanches on Tenerife and genesis of Las Cañadas caldera wall (Canary Islands), Geology, 27 (8), 739-742, 1999.

Carracedo J. C., The Canary Islands: An example of structural control on the growth of large oceanic-island volcanoes, J. Volcanol. Geotherm. Res., 60, 225-241, 1994.

Carracedo J.C., Growth, structure, instability and collapse of Canarian volcanoes and comparisons with Hawaiian volcanoes, $J$. Volcanol. Geotherm. Res., 94, 1-19, 1999.

Coello J., J.M Cantagrel, F. Hernán, J.M. Fúster, E. Ibarrola, E. Ancochea, C. Casquet, C. Jamond, Díaz de Téran and A. Cendrero, Evolution of the eastern volcanic ridge of the Canary Islands based on new K-Ar data, J. Volcanol. Geotherm. Res., 53, 251-274, 1992.

Dañobeitia J.J. and J.P. Canales, Magmatic underplating in the Canary Archipelago, J. Volcanol. Geotherm. Res., 103, 27-41, 2000.

Day S.J., J.C. Carracedo, H. Guillou, Age and geometry of an aborted rift flank collapse: the San Andrés fault, El Hierro, Canary Island, Geol. Mag., 134, 4, 523-537, 1997.

Day S.J., S.I.N. Heleno da Silva, J.F.B.D. Fonseca, A past giant lateral collapse and present-day flank instability of Fogo, Cape Verde islands, J. Volcanol. Geotherm. Res., 94, 191-218, 1999.

Duncan, R.A., Hotspots in the southern oceans - An absolute frame of reference for motion of the Gondwana continents, Tectonophysics, 74, 29-42, 1981.

Fernández C., R. Casillas, A. Ahijado, V. Perelló and A. HernándezPacheco, Shear zones as a result of intraplate tectonics in oceanic crust: An example of the Basal Complex of Fuerteventura (Canary Islands), J. Struct. Geol., 19, 41-57, 1997.

Fernández C., De la Nuez J., Casillas R., and García Navarro E., Stress fields associated with the growth of a large shield volcano (La Palma, Canary Islands), Tectonics, 21, 4, 13-1 13-18, 2002.

Funck T. and H.-U. Schmincke, Growth and destruction of Gran Canaria deduced from seismic reflection and bathymetric data, $J$. Geophys. Res., 103, 15393-15407, 1998.

Funck T. and H. Lykke-Andersen, Seismic structure of the volcanic apron north of Gran Canaria, Proceedings of the Ocean Drilling Program, Scientific Results, 157, 11-28, 1998.

García-Cacho L, Arana V., Romero C., López-González C.M., Palomo C., Acosta J., Herranz P., y Muñoz A., Submarine volcanism in the Canary Islands. Implications for tectonic controls, $2^{a}$ Asamblea Luso-Espanhola de Geodesia y Geofísica, Lagos (Portugal), S15-11, 2000.

Gee M.J.R., D.G. Masson, A.B. Watts, N.C. Mitchell, Offshore continuation of volcanic rift zones, El Hierro, Canary Islands, J. Volcanol. Geotherm. Res., 105, 107-119, 2001.

Geisslinger A., H.B. Hirschleber, M. Schnaubelt, J.J. Danobeitia and J. Gallart, Mapping of volcanic apron and the upper crust between Gran Canaria and Tenerife (Canary Islands) with seismic reflection profiling, Geo-Marine Letters, 16, 57-64, 1996.

Guillou H., J.C. Carracedo, F. Pérez Torrado, E. Rodríguez Badiola, $\mathrm{K}-\mathrm{Ar}$ ages and magnetic stratigraphy of a hotspot-induced, fast grown oceanic island: El Hierro, Canary Islands, J. Volcanol. Geotherm. Res., 1996, 73, 141-155, 1996.

Hausen, H., Contributions to the geology of Tenerife (Canary Islands), Soc. Sci. Fennicae, Comm. Phys.-Mat., 18, 254 pp, 1956. 
Hernández-Pacheco A. and J.A. Rodríguez Losada, Geología y estructura del Arco de Taganana (Tenerife, Canarias), Rev. Soc. Geol. España, 9 (3-4), 169-181, 1996.

Holcomb R.T. and R.C. Searle R.C., Large landslides from Oceanic Volcanoes, Marine Geotechnology, 10, 19-32, 1991.

Klitgord K.D. and Schouten H.S., Plate Kinematics of the Central Atlantic, Vogt P.R. and Tucholte B.E. eds, The Western North Atlantic Region: Boulder, Colorado, The Geological Society of America, Geology of North America, M, 351-378, 1986.

Krastel S., H.-U. Schmincke, C.L. Jaacobs, R. Rihm, T. P. Le Bas, and B. Alibés, Submarine landslides around the Canary Islands, J. Geophys. Res., 106, 3977-3997, 2001.

Krastel S. and H.-U. Schmincke, The channel between Gran Canaria and Tenerife: constructive processes and destructive events during the evolution of volcanic islands, Int. J. Earth Sci., 91, 629-641, 2002.

Marinoni, L.B. and G. Pasquarè, Tectonic evolution of the emergent part of a volcanic ocean island: Lanzarote, Canary Islands, Tectonophysics, 239, 111-135, 1994.

Marinoni L.B. and Gudmundsson A., Dykes, faults and palaeostresses in the Teno and Anaga massifs of Tenerife (Canary Islands), J. Volcano. Res., 103, 83-103, 2000.

Masson, D. G., Catastrophic collapse of the volcanic island of Hierro $15 \mathrm{ka}$ ago, and the history of landslides, Geology, 24, 231-234, 1996.

Masson D.G., A.B. Watts, M.J.R. Gee, R. Urgeles, N.C. Mitchell, T.P. Le Bas, and M. Canals, Slope failures on the flanks of the western Canary Islands, Earth-Science Reviews, 57, 1-35, 2002.

Mitchell N.C., G. Douglas, Masson, A.B. Watts, M.J.R. Gee and R. Urgeles, The morphology of the submarine flanks of volcanic ocean islands, A comparative study of the Canary and Hawaiian hotspot islands, J. Volcanol. Geotherm. Res., 115, 83-107, 2002.

Mitchell N.C., W.B. Dade and D.G. Masson, Erosion of the submarine flanks of the Canary Islands, J. Geophys. Res., 108, 6002, doi:10.1029/2002JF000003, 2003.

Mitchum R.M.J., P.R. Vail and J.B. Sangree, Seismic stratigraphy and global changes of sea level, Part 6: stratigraphic interpretation of seismic reflection patterns in depositional sequences, Seismic Stratigraphy-Applications to Hydrocarbon Exploration AAPG, Memoir 26, Eds: Payton C.E., 117-133, 1977.

Moore J.G., D.A. Clague, R.T. Holcomb, P.W. Lipman, W.R. Normark and M.E. Torresan, Prodigious submarine landslides on the Hawaiian Ridge, J. Geophys. Res., 94, B12, 17465-17484, 1989.

Morgan W.J., Hotspot tracks and the early rifting of the Atlantic, Tectonophysics, 94, 123-139, 1983.

Morgan J.K., G.F. Moore and D.A. Clague, Slope failure and volcanic spreading along the submarine south flank of Kilauea volcano, Hawaii, J. Geophys. Res., 108, B9, 2415, 2003.

Navarro Latorre J.M. and Coello J., Depressions originated by landslide processes in Tenerife, in ESF Meeting on Canarian Volcanism, Eur. Sci. Found., Strasbourg, France, 150-152, 1989.

Palacios D., The origin of certain wide valleys in the Canary Islands, Geomorphology, 9, 1-18, 1994.

Palomo, C., J. Acosta, A. Munoz, P. Herranz, J.L. Sanz, J. Molinero, M.A. Bécares, R. Gómez, Mapa batimorfológico del canal entre las islas de Tenerife y Gran Canaria, Ed. Instituto Español de Oceanografía, Dpto. de Geología y Geofísica, Madrid, 1998.
Ramsay J.G. and Lisle R.J., The techniques of modern structural geology, v. 3: Applications of continuum mechanics in structural geology, session 28, 2000.

Roberts J.A. and A. Cramp, Sediment stability on the western flanks of the Canary Islands, Marine Geology, 134, 13-30, 1996.

Roest, W.R., J.J. Dañobeitia, J. Verhoef and B.J. Colette, Magnetic anomalies in the Canary Basin and the Mesozoic evolution of the Central North Atlantic, Mar. Geophys. Res., 14, 1-24, 1992.

Schmincke H.-U. and R. Rhim, Ozeanvulkan 1993, Cruise $N^{\circ} 24$ Meteor-Berichte, Rep. 94-2; 88 pp., Univ. Hamburg, Hamburg, Germany, 1994.

Schmincke H.-U., P.P.E. Weaver and J. Firth, The Clastic Apron of Gran Canaria and the Madeira Abyssal Plain, JOIDES Journal, Science Operator Report Leg 157, 14-22, 1995.

Stillman C.J., A Canary Islands dyke swarm: Implications for the formation of oceanic islands by extensional fissural volcanism, Mafic Dyke Swarms, H.C. Halls and W.F. Fahring, Geol. Assoc., Can. Spec. Pap., 34, 243-255, 1987.

Stillman C.J., Giant Miocene Landslides and the evolution of Fuerteventura, Canary Islands, J. Volcanol. Geother. Res., 94, 89-104, 1999.

Teide Group: C. Palomo, J. Acosta, J. L. Sanz, P. Herranz, A. Munoz, E. Uchupi, and J. Escartin, Morphometric interpretation of the northwest and southeast slopes of Tenerife, Canary Islands, J. Geophys. Res., 102, 20325-20342, 1997.

Twiss R.J. and Moores E.M., Structural Geology, Ed. W.H. Freeman and Company, 1992.

Urgeles R., M. Canals, J. Baraza, B. Alonso, and D. Masson, The most recent megalandslides of the Canary Islands. El Golfo debris avalanche and Canary debris flow, west El Hierro Island, Jour. Geophys. Res., 102, 20305-20323, 1997.

Urgeles R., M. Canals, J. Baraza, B. Alonso, Seismostratigraphy of the western flanks of El Hierro and La Palma (Canary Islands): a record of Canary Islands volcanism, Marine Geology, 146, 225241, 1998.

Urgeles R., D.G. Masson, M. Canals, N.B. Watts and T. Le Bas, Recurrent large-scale landsliding on the west flank of La Palma, Canary Islands, J. Geophys. Res., 104, B11, 25331-25348, 1999.

Urgeles R., M. Canals, J. Roberts and the SNV "Las Palmas" Shipboard Party, Fluid flow from pore pressure measurements off $\mathrm{La}$ Palma, Canary Islands, J. Volcanol. and Geotherm. Res., 101, 253-271, 2000.

Vidal N. and O. Merle, Reactivation of basement faults beneath volcanoes: a new model of flank collapse, J. Volcanol. and Geotherm. Res., 99, 9-26, 2000.

Watts A. B. and D.G. Masson, A giant landslide in the north flank of Tenerife, Canary Islands, J. Geophys. Res., 100, 24487-24498, 1995.

Watts A.B. and D.G. Masson, Reply (to comment on 'A giant landslide on the north flank of Tenerife', Canary Islands by J. Marti). J. Geophys. Res., 103, 9949-9952, 1998.

Watts A.B. and D.G. Masson, New sonar evidence for recent catastrophic collapses of the north flank of Tenerife, Canary Islands, Bulletin of Volcanology, 63, 8-19, 2001. 